\title{
Potential for stratiform massive sulphide mineralisation in south-west England
}

A.J. Benham, F. M. McEvoy and K. E. Rollin

\begin{abstract}
This study provides an assessment of the potential for stratiform massive sulphide mineralisation in two parts of south-west England, the Central Area between Bodmin Moor and Dartmoor, and North Devon. The Central Area was selected on the basis of its tectonic, stratigraphical and lithological similarities with the Iberian Pyrite Belt (IPB) where numerous volcanogenic massive sulphide (VMS) deposits occur. North Devon is considered prospective on account of its similarities to the Harz Massif in Germany that hosts the major polymetallic sedimentary exhalative (Sedex) deposit at Rammelsberg. More than 60 stratiform mineral occurrences are known in the two areas and previous exploration, including extensive drainage geochemical surveys, geophysical surveying and drilling, has revealed stratiform mineralisation at some localities, including at Egloskerry, near Bodmin Moor, where up to $10 \% \mathrm{~Pb}$ over 4.5 metres was recorded. In North Devon, stratiform mineralisation has been recorded from a borehole at Honeymead Farm, and further evidence of potential is provided by a distinct aeromagnetic anomaly parallel to the regional strike over the upland areas of Exmoor.

The potential for the occurrence of stratiform sulphide deposits in North Devon and the Central Area has been assessed by GISbased prospectivity analysis software, Arc-Spatial Data Modeller (Arc-SDM), using knowledge-driven and data-driven modelling techniques. This analysis used both new and legacy multivariate datasets including geophysics (aeromagnetic and gravity), geochemical data, mineral occurrences, and digital 1:50 000 geological linework. This has confirmed known occurrences as well as identifying new targets for stratiform mineralisation. Zones of high prospectivity in the Central Area occur along the northern edges of Bodmin Moor and Dartmoor, in the intervening ground underlain by Lower Carboniferous strata, and in the Lower Carboniferous strata on the eastern side of Dartmoor. In North Devon prospective areas were identified at a number of localities in the Upper Devonian and Lower Carboniferous strata, with the highest potential occurring along strike from Combe Martin near Honeymead Farm.
\end{abstract}

Antony Benham (for correspondence, abenham@bgs.ac.uk), and Fiona McEvoy (fmcevoy@bgs.ac.uk) are Economic Geologists at the British Geological Survey, Keyworth, Nottingham, NG12 5GG, UK. Keith Rollin formerly worked as a Principal Geophysicist at the BGS.

Keywords: Stratiform massive sulphide, prospectivity analysis, south-west England

\section{Introduction}

South-west England (Figure 1) has a long history of metal mining from pre-Roman times. The main products were tin and copper, with subordinate lead, zinc, silver, arsenic, antimony, sulphur, iron and manganese. Over 1500 named mines are recorded in the region ${ }^{13}$. Most produced cassiterite and/or chalcopyrite from hydrothermal quartz veins and stockworks in, or close to, the Hercynian granites. However, not all the exploited mineralisation was of lode type; modern ore deposit models have permitted reexamination of the former mining districts in relation to a variety of deposit types and commodities.

This study is aimed at assessing the potential for the discovery of stratiform massive sulphide mineral deposits in two areas using GIS-based prospectivity analysis. The area between Bodmin Moor and Dartmoor, the Central Area (Figure 1), was selected for study because it has known occurrences of stratiform mineralisation and because it provides a broad geological analogy with the Iberian Pyrite Belt (IPB) of southern Spain and Portugal where major deposits of this type have been worked for many centuries

${ }^{21}$. In the second study area in northern Devon (Figure 1), a thick shallow-marine Devonian sequence occurs that is comparable to the Harz Massif in Germany which hosts the major polymetallic sulphide deposits at Rammelsberg ${ }^{19}$. 
Prospectivity analysis involves the analysis of multiple digital datasets such as geophysics, geochemistry and geology that are integrated into a single prospectivity map that identifies favourable areas for new deposits based upon the parameters of a particular mineral deposit model. In 2001, Rollin et al. undertook a preliminary prospectivity analysis for stratiform base-metal sulphides in south-west England ${ }^{29}$. This study focused on Devon and east Cornwall and involved the use of 1:250 000 digital geology and a BGS-developed prospectivity-modelling package known as XMAP.

The present investigation concerns two areas that are regarded as favourable for the occurrence of stratiform base-metal sulphide deposits (Figure 1): the Central Area, located between the Bodmin Moor and Dartmoor granites, and the North Devon area, located along the north Devon coast extending into Somerset and inland as far as Barnstaple. This present study utilises an improved prospectivity methodology, the Spatial Data Modeller tool used with Arcview (Arc-SDM). It also uses new data integrated with legacy data within a framework provided by modern published mineral deposit models for stratiform base-metal sulphide deposits. The key items of data incorporated into the new prospectivity analysis are: legacy aeromagnetic data digitised and interpreted with new procedures, revised geological models and new digital 1:50 000 geological data, new drainage geochemistry data, and mine and mineral occurrence data held in the BGS Mineral Occurrence Database (MOD).

\section{Geology}

South-west England has a complex geological history and the region lies in the outer and northernmost zone of the Variscan orogen, the Rhenohercynian terrane. The nature of the basement to the Rhenohercynian zone is uncertain: in the north a series of stacked thrusts that have affected Devonian and Carboniferous strata probably rest on a basement that is part of the Avalonian terrane (Figure 1). The most southerly point in the south-west is the Lizard peninsula, a fragment of Devonian oceanic floor of mainly ultrabasic rocks, most of which have been altered to serpentinite. This may be linked to the Start series of schists and gneisses (in Devon) by a series of thrusts and marks the edge of the Amorican Terrane.

Lower Devonian sedimentary rocks in the Central Area are separated from those in North Devon by a broad zone of fine-grained sedimentary Carboniferous rocks (the Culm Basin) in central Devon (Figure 1). In the south-west of the basin, the Lower Carboniferous succession consists of a thin sequence of black shales, calcareous mudrock and bedded chert, with some tuffs and spilitic lavas. The Upper Carboniferous is a thick succession of interbedded turbidite sandstones and mudrocks known as the Culm Measures. These rocks have undergone low-grade metamorphism and Variscan deformation; they underlie most of Devon and Cornwall to the north of the Dartmoor and Bodmin Moor granites.

\section{Central Area}

The large granitic bodies of Dartmoor and Bodmin Moor dominate the Central Area (Figure 1). These were emplaced over an interval of approximately 30 Ma commencing at the Permian-Carboniferous boundary and they form part of the Cornubian batholith that extends from Dartmoor through Cornwall to the Isles of Scilly ${ }^{33}$. The economic importance of these rocks is well known due to their association with mineral deposits that have been exploited since pre-Roman times.

The geology between the Bodmin Moor and Dartmoor granites is composed of a complex series of parautochthonous and allochthonous sequences of Carboniferous and Middle and Upper Devonian sandstones and slates that have been thrust northwards into nappes during the Variscan orogeny (Figure 1). Within these nappes and the parautochthon there are more than 30 named formations spanning the stages from Famennian to Namurian including many formations with black shale members and cherts. Stratiform manganese silicate-carbonate mineralisation derived from contemporaneous submarine hydrothermal activity occur within the chert beds.

The central belt between Bodmin Moor and Dartmoor includes prospective host formations for stratiform sulphide deposits in both parautochthonous and allochthonous sequences. Commercial drilling near Egloskerry (Figure 2) in rocks of Late Devonian to Early Carboniferous age identified stratiform lead-zinc mineralisation ${ }^{16}$. 


\section{North Devon}

In North Devon (Figure 1) transitions between marine and non-marine conditions dominate the stratigraphy. The Middle to Late Devonian boundary occurs above a sequence of fluvial and deltaic sandstones, within a marine sequence dominated by shales or mudstones, with thin limestone beds in the lowest part. The thickness of the sandstone and shale units is difficult to measure due to structural repetition and the lack of zonal fossils, but some formations in the area are in excess of several hundreds of metres. The oldest strata exposed belong to the marine Lynton Formation (Figure 3). These are conformably overlain by the Hangman Sandstone Formation that marks a major regressive and transgressive event. This formation is in turn is overlain by the Ilfracombe Slate Formation (subdivided by later BGS mapping into the Kentisbury Slates Member, the Lester Slates and Sandstones Member, and the Wild Pear Slates Member).

In the Combe Martin district the Ilfracombe Slate Formation contains lead-zinc-silver deposits that provided the basis of the historic mining industry in that area ${ }^{32}$. The mines probably date back to the $13^{\text {th }}$ century ${ }^{9}$ and have been closed and re-opened several times since, with production finally ceasing in the 1940s. Along strike to the east, drilling at approximately the same stratigraphic level at Honeymead Farm (Figure 3) identified disseminated Fe-sulphide (pyrrhotite) mineralisation beneath Exmoor 14.

\section{Previous investigations for stratiform base-metal sulphide deposits}

Extensive exploration activity, ranging from regional reconnaissance surveys to detailed investigations, has been carried out in both areas of study. The DTI-funded Mineral Reconnaissance Programme (MRP), carried out by the BGS from 1971-1996, produced 37 reports and data releases related to south-west England. In addition there are 51 reports on commercial exploration work carried out under the Mineral Exploration and Investment Grant Act (MEIGA) that operated from 1971-1984. The BGS 1:10 000 scale mapping programme and associated regional gravity and aeromagnetic surveys ${ }^{6,7}$ also provide a large amount of relevant data that underpins exploration and assessment of the mineral resources in the region. The most recent study related to base-metal mineralisation assessed the potential for the occurrence of stratiform base-metal sulphide mineralisation in Devon and east Cornwall using knowledge-based prospectivity analysis ${ }^{29}$.

\section{Central Area}

Regional reconnaissance geophysical surveys carried out by BGS in the 1950s identified a prominent high frequency aeromagnetic anomaly in the central area of Devon and east Cornwall ${ }^{7}$ which approximately follows the mapped outcrop of Lower Carboniferous strata along the northern margins of the Dartmoor and Bodmin Moor granites (Figure 2). The form of the magnetic anomaly indicates that its source has a strong Natural Remnant Magnetisation (NRM) vector. The most important ferromagnetic mineral in the area was shown to be pyrrhotite that has a Curie temperature in the range $270-330^{\circ} \mathrm{C}$. The pyrrhotite appears to have been formed at about the time of granite intrusion, either by metasomatism ${ }^{10}$ or by recrystallisation of syngenetic pyrite ${ }^{3}$. A strong geochemical soil anomaly was identified in 1981 by RioFinex at Egloskerry, two miles west of Launceston, Cornwall (Figure 2). Anomalous Pb values in soils, in excess of 4000 ppm, occurred at two localities that were subsequently drilled. Zinc, and to a lesser extent $\mathrm{Cu}$ and $\mathrm{Mn}$, were also enriched at these sites. In one borehole significant lead mineralisation was intersected with $10 \%$ Pb over $4.5 \mathrm{~m}$ (4.1 m true thickness) in a $45 \mathrm{~m}$ thick laminated siltstone unit forming part of the Lower Carboniferous volcano-sedimentary sequence. Other boreholes in the area intersected 1-2\% combined $\mathrm{Pb}$ and $\mathrm{Zn}$ over 1-2 m.

In the Bovey Tracey area of east Dartmoor (Figure 2), MRP drilling investigated geophysical anomalies associated with clusters of soil geochemical anomalies ${ }^{2}$. This identified disseminated and thin, discontinuous stratabound veinlets of sulphides in shales, cherts and tuffs close to the Lower-Upper Carboniferous boundary. Galena and sphalerite with minor chalcopyrite, arsenopyrite 
and loellingite are associated with pyrite, quartz and siderite. Chemical analysis of this drillcore revealed high Zn values in some sections, one containing 2\% Zn over $3 \mathrm{~m}$. Finely disseminated galena and sphalerite had not been reported previously from the Teign Valley and their discovery indicated potential for this type of deposit in the condensed Lower Carboniferous sequence of this district. The results of these and other investigations carried out in this area are summarised in Table 1.

\section{North Devon}

Drainage geochemical surveys over Exmoor and the Brendon Hills (Figure 1) carried out by the MRP in the mid-late 1980s identified several areas of anomalous $\mathrm{Zn}, \mathrm{Pb}, \mathrm{Ni}, \mathrm{Cu}, \mathrm{Sb}$, and $\mathrm{Ba}^{17}$. Some of these anomalies relate to vein-style mineralisation, but others may reflect stratiform base-metal and barytes mineralisation.

Regional aeromagnetic surveys carried out by the BGS in the 1950s identified a distinct aeromagnetic anomaly with an amplitude of about $60 \mathrm{nT}$ trending west-north-west-east-south-east over the upland areas of Exmoor approximately following the boundary between the Ilfracombe Slates and the Morte Slates (Figure 3). A less prominent linear anomaly to the south occurs over the upper part of the Morte Slates, with maximum amplitudes in the west. Detailed soil geochemical studies over the aeromagnetic anomalies identified minor $\mathrm{Zn}-\mathrm{Pb}$ enrichments in some areas and a general association of $\mathrm{Zn}$ in soil with the magnetic anomaly ${ }^{17}$. At the site of one of these anomalies, Honeymead Farm (approximately $25 \mathrm{~km}$ south-east of Combe Martin), two boreholes were drilled as part of the BGS mapping programme ${ }^{14}$. These identified pyrrhotite mineralisation in the form of disseminations on the cleavage faces as well as pyrite occurring as fine disseminations in sandstones, with calcite in tension gashes and minor veins. The results of the principal investigations carried out in this area are summarised in Table 1.

\section{Prospectivity Analysis}

Mineral deposit models are syntheses of large amounts of data that provide an essentially qualitative basis for exploration and resource assessment. Such models can be used to identify the key exploration criteria for a particular type of deposit and thus form the basis for analysis of the mineral potential of a region. Geographical Information Systems (GIS) have become the standard platform in mineral exploration to coordinate and manage these datasets. GIS facilitates the querying and analysis of the data to determine which parameters are critical or subsidiary to the mineralisation process and allows the structured integration and modelling of these often-voluminous datasets to look for patterns and associations that may otherwise not be apparent. Data integration models in GIS are divided into two categories, data-driven models (Weights of Evidence modelling and logistic regression) and knowledge-driven models (Fuzzy Logic and neural network) ${ }^{5}$. Data-driven approaches such as Weights of Evidence are probability-based techniques for mapping mineral potential using the spatial distribution of known mineral occurrences. The approach aims to relate or 'train' all specified datasets to known occurrences of the particular deposit type within the region and, by association, highlight those data relationships which closely mimic the patterns at the known occurrences. Weights are estimated from the measured association between known occurrences and the values on the maps to be used as predictors. The output of Weights of Evidence modelling is a map of posterior probability, or the degree to which each pixel resembles one or more of the training points (the known occurrences).

Weights of Evidence modelling has been applied to variety of deposit types worldwide including favourability mapping for volcanogenic massive sulphide (VMS) deposits in Manitoba ${ }^{43}$, porphyry copper deposits in northern Iran ${ }^{35}$, tin-tungsten-uranium mineralisation in Nova Scotia ${ }^{41}$, and diamond exploration at Lac de Gras, Northwest Territories ${ }^{42}$. Knowledge-driven analyses establish the relationship between the spatial exploration datasets and the exploration model and are often employed in regions without known mineral occurrences with which to 'train' the exploration datasets. Knowledge-driven techniques such as Fuzzy Logic are subjective in that the 'explorationist' determines the relative significance of the exploration datasets and assigns a significance weighting based on the exploration model. Knowledge-based prospectivity mapping is 
achieved by extracting the spatial relationships from exploration datasets on the basis of the exploration model, quantifying these spatial relationships and integrating them using mathematical operators chosen by the user. The output of Fuzzy Logic modelling is a map of mineral potential. This can be directly compared with the posterior probability map generated by the Weights of Evidence model allowing the user to compare the utility of each model for a particular study. Fuzzy Logic prospectivity analysis has been applied over a number of different deposit types throughout the world, examples being Mississippi Valley Type (MVT) mineralisation ${ }^{12}$, porphyry copper deposits in northern Iran ${ }^{36}$, and orogenic gold deposits in the Yilgarn Block, Western Australia 15 .

Various techniques can be applied to generate mineral potential maps within a GIS environment. Arc-Spatial Data Modeller (SDM) software ${ }^{18}$, developed by the United States Geological Survey and the Geological Survey of Canada, provides the ability to conduct both data-driven and knowledge-driven analysis. All these methods combine two or more evidential themes to generate a response theme that is a map that predicts favourable locations for mineral deposit occurrences.

Prospectivity analysis is based on a general series of procedures, which can be grouped into five key stages:

1) A review of the mineral deposit model;

2) Determination of the key exploration indicators from the mineral deposit model;

3) Review of dataset availability for the area under investigation, data processing, interpretation and analysis to extract the key indicators;

4) Assignment of weightings, zones and styles of influence to key indicators (expert parameterisation); and

5) Calculation of prospectivity using knowledge-driven or data-driven methods

For a detailed explanation of the mathematics underlying both Weights of Evidence and Fuzzy Logic the reader is referred to Bonham-Carter ${ }^{5}$.

\section{Mineral Deposit Models and Key Exploration Criteria}

Exploration criteria are defined on the basis of mineral deposit models built from a knowledge of similar deposits world-wide, modified by specific features of any known local mineralisation in the area being assessed. The degree of confidence and value that can be attached to the prospectivity maps depends on the availability, quality and relevance of the data, together with the reliability of the exploration model.

Rollin et al. identified many geological similarities between the Central Area between Bodmin Moor and Dartmoor and the Iberian Pyrite Belt (IPB) in southern Spain and Portugal, where numerous VMS deposits occur ${ }^{29}$. They also compared the geological environment of the Exmoor district to the setting of the major Sedex-type polymetallic sulphide deposit at Rammelsberg in Germany. Exploration criteria for both deposit types include essential general parameters and specific local features which contribute to favourability. Many essential parameters for both deposit classes are present, although the extent and distribution of many are poorly known.

\section{IPB-type model and parameters}

VMS deposits form on or close to the seafloor from venting metal-rich solutions. They occur in a range of tectonic settings characterised by the presence of submarine volcanic rocks. Mineralisation typically occurs in a volcanosedimentary succession that includes bimodal piles of rhyolite-basalt lavas, tuffs and breccias with varying quantities of interbedded clastic sediments, commonly fine-grained (mudstones) ocean-floor deposits. The IPB is the largest accumulation of VMS mineralisation in the world with more than 80 known deposits containing sulphide resources (ore mined and reserves) in excess of $1700 \mathrm{Mt}$ totalling 4.6 
Mt Cu, 13 Mt Pb, 34.9 Mt Zn as well as substantial tonnages of Au and Ag ${ }^{21}$. The IPB mineralisation is dominated by pyrite and the VMS deposits typically comprise a concordant lens of massive sulphide, containing at least $60 \%$ sulphide, which is underlain by a discordant stockwork or stringer zone of vein-style mineralisation enclosed within a pipe of hydrothermally altered rock. A deposit may comprise several individual massive sulphide lenses and their associated stockwork zones. Mineralisation tends to occur at a single stratigraphic interval within which several individual deposits may be developed.

The IPB formed in a basin located at the passive margin of an exotic terrane that suffered a northward oblique subduction and later collision with the autochthonous Iberian Terrane during the Variscan times ${ }^{39}$. Remnants of this exotic terrane include the South Portuguese Zone (SPZ) that hosts minor IPB-equivalent mineralisation in the Variscan Arc of south-west Ireland and south-west England ${ }^{27,24}$. The succession in the IPB can be divided into three units (Figure 4):

1. The Devonian pre-volcanic phyllite-quartzite (PQ) group of monotonous shales and sandstones, with an increasing proportion of sandstones in the upper part of the sequence of Upper Famennian age.

2. The volcano-sedimentary complex (VSC) comprises a series of felsic and mafic volcanic episodes. Felsic volcanic rocks are commonly pyroclastic and may be subaerial or shallow-marine facies. The mafic rocks are either submarine volcanic or subvolcanic in origin.

3. The post-volcanic Lower Carboniferous Culm Group (CG) comprises turbiditic sediments filling a subsiding basin.

The Central Area shares lithological and stratigraphical similarities with the IPB as illustrated in Figure 4. Both regions comprise a series of alternating fine-grained sediments and volcanic rocks formed in a submarine environment. The Milton Abbot Formation and the Tintagel Volcanic Formation contain reworked volcanic rocks interpreted as analogous to the basic lavas and tuffs of the IPB. The Meldon Chert Formation and the Crackington Formation are also comparable to lithologies within the IPB.

Iberian Pyrite Belt-type deposits are dominated by Fe and S and most are zinc-lead-copper type, with typical ore grades of $2 \%$ Zn, $1 \% \mathrm{~Pb}$ and $0.5 \% \mathrm{Cu}$, though locally $\mathrm{Cu}$ grades exceed $1 \%$. Most deposits have relatively low Au contents, typically about $1-$ 1.5 ppm, with Ag contents mostly in the range 20-60 ppm. Ore-element zoning is not common in the IPB. The sulphide deposits are stratigraphically associated with detrital and volcaniclastic horizons overlying the felsic volcanic rocks. They are directly related to black shale horizons that range from $5 \mathrm{~m}$ to more than $200 \mathrm{~m}$ thick. It has been suggested that most of the massive sulphide was emplaced close to the hydrothermal feeder zone ${ }^{31}$.

Exploration criteria for IPB-type deposits, including both the essential general parameters and more specific local features and their significance, are summarised in Table 2, where their presence in the Central Area in also indicated.

\section{Sedex-type model and parameters}

Sedimentary exhalative (Sedex) deposits are syngenetic massive sulphide deposits hosted by marine sedimentary rocks and were formed by submarine exhalative fluids during basin development. They typically form within restricted marine basinal sedimentary sequences in an epicratonic tectonic setting, similar to North Devon. They contain the largest proportion of lead and zinc resources of any class of deposit in the world. Sedex deposits provide more than $25 \%$ of global zinc and lead production and are typically an order of magnitude larger than VMS deposits.

They are typically stratabound, tabular to lens shaped and are composed of many beds of sulphide and/or barytes laminae ${ }^{22}$. The lenses are frequently stacked and more than one horizon may be economic. The orebody may be part of a sedimentary succession often hundreds of metres thick, and the lenses may persist horizontally for tens of kilometres. Deposits occur in anoxic basinal 
sediments capping syn-rift sequences in failed intracontinental rifts or in fault-bounded grabens on rifted continental margins. They commonly have a close spatial and temporal relationship with mafic volcanic rocks that vary from tholeiitic to alkaline in composition but felsic volcanic rocks are uncommon. The host facies are typical of anoxic, starved-basin environments, including carbonaceous cherts, shales, siltstones and coarser clastic rocks, breccias and carbonates. The depositional environment is interpreted as restricted second- and third-order basins within linear marine, fault-controlled trough and basins. Water depth varies from deep marine to shallow water restricted shelf conditions. The majority of Sedex deposits occur in Middle Proterozoic and Devonian-Lower Carboniferous strata.

The stratigraphical and tectonic setting of the Devonian sediments on Exmoor may be compared with those of the Harz basin which hosts the major Sedex copper-lead-zinc-barytes deposit at Rammelsberg. This deposit, now exhausted, was worked for over 1000 years. The estimated total tonnage extracted was about $30 \mathrm{Mt}$ with an average grade of $14 \% \mathrm{Zn}, 6 \% \mathrm{~Pb}, 2 \% \mathrm{Cu}, 140 \mathrm{~g} / \mathrm{t} \mathrm{Ag}$, $1 \mathrm{~g} / \mathrm{t} \mathrm{Au}$ and $20 \%$ barytes $^{19}$. The Rammelsberg deposit is hosted by the Middle Devonian (Eifelian) Wissenbach shale (Figure 5) occurring along a structural line that marks rapid changes in the thickness of dark shales and is the focus of mafic volcanic rocks that occur in the thicker part of the unit. The lateral equivalent of the ore horizon has been recognised up to $7 \mathrm{~km}$ from the Rammelsberg deposit.

The Harz basin and North Devon are both underlain by alternating sequence of shales and sandstones of Middle to Late Devonian age (Figure 5). These formations were deposited in anoxic marine basins in the Rhenohercynian Zone of the Variscan orogen. The ore horizon of the Rammelsberg deposit is broadly equivalent to the Combe Martin Slates Formation that hosted much of the leadzinc-silver mineralisation at Combe Martin.

Geochemical anomalies are commonly present around Sedex deposits and may be zoned with lead enrichment closest to the vent passing outwards into more zinc-rich facies. Copper and Mn anomalies may also be found around the deposit, while Ba anomalies may also occur in the more distal facies.

Exploration criteria for Sedex deposits, including both the essential general parameters and more specific local features and their significance are summarised in Table 3, where their presence in North Devon is also indicated.

\section{Data and exploration criteria}

The key exploration criteria for IPB-type (Table 2) and Sedex (Table 3) mineral deposits determined the selection of datasets for integration into the prospectivity analysis. The data classes utilised were geology, stream-sediment geochemistry, geophysics including both aeromagnetic and gravity data, mineral occurrences and regional structure.

Geology

The study region covers more than twenty British Geological Survey 1:50 000 geological map sheets. Many of these sheets were originally surveyed between 1870-1900 but some sheets have since been revised and all are available digitally and fully attributed. Rollin et al. used 1:250 000 scale digital geological linework in their prospectivity analysis in south-west England as the digital capture of the 1:50 000 linework had not been completed ${ }^{29}$. The recent release of this dataset was one of the key driving forces behind this study.

In the Central Area, the Upper Devonian and Lower Carboniferous sequences have been divided into numerous formations separated by tectonic boundaries. By analogy with the IPB, chert and black shale horizons identified in many of these formations are important target lithologies for massive sulphide deposits. Elsewhere, the geological linework has been generalised in part due to the semi-regional resolution of the prospectivity mapping. 
The Upper Devonian and Lower Carboniferous sequences in north Devon shares many similarities with that of the Harz Massif of Germany, host to the Rammelsberg deposit. The ore horizon in the Rammelsberg deposit is the Wissenbach Shale, a dark grey shale and sandstone sequence of Eifelian age (Middle Devonian). The Eifelian Hangman Grits in Devon although more arenaceous than the Harz Eifelian sequences, are overlain by the Ilfracombe Slates, which are primarily grey slates with minor sandstone (Figure 4). Recent mapping in the Combe Martin area has led to the Ilfracombe Slates Formation being subdivided into the Wild Pear Slates Member, the Lester Slates and Sandstone Member and the Kentisbury Slates Member (Figure 9). Further to the east over parts of Exmoor and the Brendon Hills, the Ilfracombe Slates Formation is undifferentiated.

Structure

South-west England has undergone major thrusting and faulting during the Variscan orogeny and consequently there are a large number of structural lineaments present in both study areas. The identification of basement lineaments, that represent deep faults that may have acted as a conduit for mineralising fluids, is important in the definition of prospective areas.

In a description of the key features and evolution of one of the IPB's most important deposits at Neves-Corvo in Portugal, Relvas et al. ${ }^{26}$ highlighted the requirement for a fault-controlled, seawater-dominated convection cell system to drive hydrothermal activity and for scavenging deeper, multi-sourced metal-rich fluid contributions. Deep fault systems, like those bounding subsiding basins, assist in stabilising long-lived paths of fluid flow. At the Feitais deposit in Aljustrel, southern Portugal, copper stockworks underlie the thicker sections of the deposit and appear to be spatially associated with growth faults that controlled basin geometry. These faults also influenced the distribution of tuffaceous and cherty (exhalative) units that overlie the sulphides ${ }^{11}$.

The Central Area is transected by a dominant north-north-west trending fault set and a less prominent but potentially significant north-north-east fault set recorded by both field mapping and from the interpretation of regional gravity and aeromagnetic data. The latter fault set can be seen as lineaments in images of the gravity and magnetic data for the UK and surrounding countries ${ }^{6,7}$. Rollin et al. suggested that these structures might influence the genesis of IPB style mineralisation in the Central Area ${ }^{29}$. In North Devon, structural mapping and geophysical interpretation of data has not been comprehensively recorded and only limited data is available, in particular for the area around Exmoor.

Geophysics

Gravity and aeromagnetic datasets were incorporated into the prospectivity analysis. Regional gravity data collected as part of a national survey by the BGS have a distribution of about one station per $\mathrm{km}^{2}$. Detailed gravity surveys have also been carried out at several localities across the region as part of the MRP programme ${ }^{38}$ and to support the BGS mapping programme ${ }^{28}$. Stratiform massive sulphide deposits are commonly associated with a small (typically 1-2 mGal) positive residual anomaly although some of the IPB deposits have associated small high-frequency residual anomalies up to $4 \mathrm{mGal}{ }^{29}$. Although the regional gravity survey of the UK is undersampled compared with exploration practice in the IPB, an attempt was made to identify residual anomalies that might be targets for further exploration ${ }^{30}$.

Regional aeromagnetic data collected by the Hunting Group for the BGS in 1957-58 was used to calculate the residual magnetic anomalies with the aim of accentuating the higher frequency components of the observed data. This residual magnetic anomaly has been used in the prospectivity analysis of both areas. In addition, the analytic signal magnitude was calculated to give an indication of the position of the source of the magnetism regardless of the direction of the total magnetisation vector. These anomalies represent magnetic pyrrhotite and may also be indicative of primary stratiform sulphide mineralisation. Many of the larger postulated magnetic sources identified by the analytic signal have not yet been tested by drilling. Only the Wilsey Down borehole is sited on or close to a local maximum in the analytic signal field, and drilling here identified substantial thicknesses of disseminated pyrrhotite (Table 1). In the Central Area, the magnitude of the analytical signal of the residual magnetic field has been used to indicate sources for the magnetised zone north of Bodmin Moor and Dartmoor. 


\section{Geochemistry}

In addition to the MRP survey data, stream-sediment sampling was recently carried out in the catchment of the River Tamar (920 $\mathrm{km}^{2}$ ) area as part of the national Geochemical Baseline Survey of the Environment (G-BASE) regional geochemical mapping programme. Nearly 500 sites were sampled and analysed for 45 elements including $\mathrm{Zn}, \mathrm{Pb}, \mathrm{Cu}$ and $\mathrm{Mn}$ with maximum values of 1901 ppm for Zn and 8000 ppm Cu recorded in the region ${ }^{25}$.

The pathfinder elements $\mathrm{Pb}, \mathrm{Zn} \mathrm{Cu}$ and $\mathrm{Mn}$ were selected for delineating areas of potential Sedex style mineralisation in North Devon. However, the legacy of past mining activity locally presents a significant problem for the application of stream-sediment geochemistry to exploration in the Central Area. Background values for $\mathrm{Cu}$ and $\mathrm{Mn}$ in the Lower Carboniferous rocks are much higher than in other groups with the geochemical data indicating multi-modal distributions reflecting the populations from various lithologies, mineralisation and contamination. This has been taken into account in the prospectivity analysis by adjustment of the threshold (95\% values) values for $\mathrm{Cu}, \mathrm{Pb}$ and $\mathrm{Zn}$ in stream-sediment samples collected over Lower Carboniferous rocks. Mine workings and mineral occurrence data have been incorporated into the prospectivity analysis in two ways. Firstly, many of the manganese mines represent stratiform deposition of oxide ores that may be lateral equivalents of base-metal sulphide deposits. Accordingly, in addition to known occurrences of stratiform base-metal mineralisation, the presence of manganese mineralisation has been used as positive evidence to support the potential occurrence of sulphide ores. Secondly, the mines in the area provide evidence for the occurrence of various metals in hydrothermal vein systems. These data have been used to filter the drainage geochemical data in an attempt to remove the influence of vein mineralisation. In practice, geochemical anomalies for $\mathrm{Cu}, \mathrm{Zn}$ and $\mathrm{Pb}$ have been excluded from the prospectivity analysis if the sample site is located within $2 \mathrm{~km}$ of a mine working which records one or more of these elements as either a main or secondary commodity.

In addition to $\mathrm{Cu}, \mathrm{Zn}$ and $\mathrm{Pb}, \mathrm{Mn}$ was incorporated into the prospectivity analysis with high values occurring over Lower Carboniferous rocks in the Teign valley and in the central zone near Launceston and Tavistock ${ }^{29}$. Manganese values over Middle Devonian rocks are generally low. The main exploration criteria utilised in the prospectivity analysis for IPB deposits in the Central Area are summarised in Table 4.

\section{Prospectivity mapping in the Central Area and North Devon}

The Weights of Evidence method was applied to the prospectivity analysis for IPB-type deposits in the Central Area. Forty-seven polymetallic stratiform mineral occurrences were used to 'train' the various exploration datasets for the area. Fuzzy Logic prospectivity analysis was carried out for Sedex deposits in North Devon. The Fuzzy Logic method of analysis was selected as the modelling technique due to the lack of known mineral occurrences in the North Devon area.

\section{Weights of Evidence modelling: Central Area}

Bedrock lithology, residual aeromagnetic and gravity anomalies, aeromagnetic analytical signal, geophysical lineaments, streamsediment geochemistry and mapped structures, selected as the key exploration criteria, were gridded, processed and reclassified to generate binary-class evidential maps described below (Table 4). The known mineral occurrences were divided into two subsets: the training and the validation subsets.

Inspection of inter-element correlations showed that $\mathrm{As}$ and $\mathrm{Sb}$ should not be used in the analysis, whereas $\mathrm{Mn}, \mathrm{Pb}, \mathrm{Zn}, \mathrm{Ba}$ and $\mathrm{Cu}$ were sufficiently uncorrelated and thus acceptable for integration using Weights of Evidence. In order to convert the data into a binary evidential theme, each theme is integrated with the training point theme and the spatial relationship between both is calculated to derive a suitable cut-off value. This relationship is termed the 'contrast' and the greater the value, the stronger the relationship between the exploration model data layers and the evidential theme. The contrast value can be positive, indicating a spatial correlation with the associated with the mineralisation, or negative, indicating that no relationship exists between the two 
themes. The contrast sign is used to reclassify the theme into a binary-class layer of true (positive contrasts) and false (negative contrasts). The contrast values for each class of the evidential maps were computed using the training subset only. Pairwise test of conditional independence was carried out on all 11 binary evidential themes using Arc-SDM.

The key predictor factors determined for IPB mineralisation in the Central Area, represented by positive contrast values are shown in Table 5. They are black shales and chert horizons, Mn in stream sediments and mapped regional structures. The strongest overall predictor, lithology, returned a range of values reflecting the varying prospectivity of each lithology for IPB type deposits. The strongest contrast values are from slate and chert formations within the study area, agreeing strongly with the IPB mineral deposit model.

The contrast values of the binary-class evidential maps were combined and threshold values determined to generate a rank favourability map for IPB-type deposits (Figure 8). A comparison of the spatial distribution of the predicted high favourability areas and the validation subset showed that most of the validation subset fall in the areas of high favourability. In addition, several new areas with high favourability were mapped.

Fuzzy Logic Modelling: North Devon Area

Bedrock lithology, aeromagnetic analytical signal, magnetic and gravity lineaments, stream sediment geochemical anomalies and mapped structures were selected as the key exploration parameters for the prospectivity analysis for Sedex deposits in North Devon. Known mineral occurrences were included as an evidential theme as Fuzzy Logic does not require known occurrences of mineralisation to be used as training.

In Fuzzy Logic, multiclass themes such as maps are classified on the basis of their mineral favourability using a fuzzy concept that allows favourability to be assigned on a continuous scale from 0.0 (non-membership) to 1.0 (full membership) ${ }^{5}$. For example, As values in a geochemical dataset may be divided according to percentile values, such that values above the $75 \%$ level in the cumulative dataset might be considered anomalous (Fuzzy set membership $=1.0$ ) while values below the 25\% level might be considered not anomalous (Fuzzy set membership =0.) Values between 25\% and 75\% would therefore be assigned values on a scale from 0.1 to1.0.

Each evidential theme in the Sedex exploration model was assigned a fuzzy membership or significance value on the basis of the mineral deposit model (Table 6 and 7). The weighting applied is dependent on the relative importance and reliability of one data set against another. Areas with an absence of any favourable features, primarily due to a lack of sufficient data were assigned a no data value (-99), the use of which signifies that the data has no impact on the model.

A structural proximity analysis (“buffering”) was performed on linear features (faults, lineaments) and point themes (mineral occurrences) enabling a cumulatively decreasing weighting to be applied with distance from the feature. Features in each of the three themes were buffered at $500 \mathrm{~m}$ intervals. The fuzzy membership assigned to each buffer within each theme is presented in Table 7. Areas of known mineralisation were assigned the greatest fuzzy membership decreasing with distance from the occurrence.

The North Devon prospectivity map was created by combining each evidential theme using fizzy logic operators in a series of steps, as depicted in the schematic inference model (Figure 6). Fuzzy memberships from each theme were combined using fuzzy operators to produce a gradational map of the mineral potential of the terrain. Five operators have been found to be useful for the combination of exploration datasets ${ }^{1}$ : fuzzy AND, fuzzy OR, fuzzy algebraic product, fuzzy algebraic sum (FAS) and fuzzy gamma operators. The Fuzzy Logic operators used to combine the fuzzy sets were selected on the basis of the relationships of the data layers and on the interdependence of the data. In the first level of the model (Figure 6) the fuzzy OR operator was used to combine the geochemical elements $\mathrm{Zn}$ and $\mathrm{Mn}$, and $\mathrm{Pb}$ and $\mathrm{Cu}$ in stream sediments; the results were then incorporated into the 
second level of the inference model. The OR operator is used when two map patterns represent the same level of evidence, and the combinations suggest evidence at higher probability ${ }^{40}$. The second level of the model combined the evidential themes using FAS to output a map of the potential for Sedex mineralisation in the North Devon area. FAS is the complement to the algebraic product and its use yields results larger than or equal to the largest contributing fuzzy membership value. Two pieces of evidence that both favour a hypothesis reinforce one another and the combined evidence is more supportive than either piece of evidence taken individually ${ }^{5}$.

\section{Results}

Central Area

The results of the prospectivity analysis for the Central Area are presented in Figure 8. Key features of the main target areas for IPB deposits are summarised in Table 8 and are described below.

A. Along the northern edge of the Bodmin Moor granite. This area contains numerous formations with black shales, many thrusts and east-west trending faults, and several known occurrences of stratiform mineralisation. Manganese anomalies in drainage samples are widespread, while local high tenor stream-sediment anomalies for Zn are also present. There are also several zones where the magnitude of the analytic signal of the magnetic anomaly exceeds $350 \mathrm{nT} / \mathrm{km}$.

B. To the west of the Dartmoor granite in the Chillaton area (Figure 2). This area also contains numerous formations with black shales, many thrusts and has the highest concentration of known occurrences of stratiform mineralisation in the region, where prospective targets occur in the thrust-and-nappe terrane of the Lower Carboniferous strata associated with minor positive gravity anomalies. The residual gravity anomalies either side of the Bovey Tracy basin (and at Tavistock) cover a larger region and are more likely due to structure in the basement and to data sampling around the Dartmoor granite than to features in the thrust sequence.

C. Immediately north of Tavistock, to the west of the Dartmoor granite, is a prospective area that is not related to any existing mineral occurrences (Figure 2). This area is underlain by Lower Carboniferous sediments and minor volcanic rocks.

D. To the east of Okehampton, near Dunsford (Figure 2), is an area where the prospectivity is based on shallow magnetic anomalies data and a significant maximum in the analytic signal of the residual magnetic data. This suggests prospective terrain beneath Upper Carboniferous strata on Whiddon Down. This area also has the highest $\mathrm{Zn}$ and $\mathrm{Pb}$ anomalies in the area with 4000 and 2100 ppm respectively. It also includes four manganese occurrences and has chert, shale and volcanic formations.

E. Around Ilsington to the east of the Dartmoor granite (Figure 2). The geology of this area contains a number of chert, slate and volcanic formations and there is one known manganese occurrence. The area also has an anomalous analytic signal value of $525 \mathrm{nT} / \mathrm{km}$ and a $\mathrm{Pb}$ geochemical anomaly of $1000 \mathrm{ppm}$.

\section{North Devon}

It is more difficult to generate a reliable prospectivity map for the Exmoor area because of the paucity of available data. Particular relevance has therefore been placed on geology and stream-sediment geochemistry. Key features of prospective areas for Sedex deposits in north Devon are shown in Figure 10 are summarised below in Table 9. 
A. Along the boundary between the Ilfracombe Slates Formation and the Morte Slates Formation, parallel to the regional strike. This area is prospective due to the presence of shallow-source linear magnetic anomalies together with drainage geochemical anomalies for $\mathrm{Zn}, \mathrm{Mn}$ and locally $\mathrm{Pb}$. Previous ground investigation of the magnetic anomalies and subsequent drilling at Honeymead Farm (Figure 3) has also indicated significant pyrrhotite mineralisation interpreted as forming from syngenetic pyrite ${ }^{14}$. The historical lead-zinc-silver mining area around Combe Martin has, however, not been highlighted as prospective for Sedex deposits. This may be due to the style of mineralisation worked there not being of Sedex-type since mineralisation observed at Lester Point near Combe Martin (Figure 3), consists of thin and discontinuous galena veins not consistent with a stratiform sulphide deposit. The lack of a gravity anomaly in the Combe Martin area may also be because most of the lead mineralisation has been worked out.

B. The anomaly in the Brendon Hills area is related to barytes vein deposits in the area and associated anomalous Ba values recorded from MRP geochemical sampling ${ }^{17}$. Sedex deposits typically contain high Ba values with up to 20 $\%$ at Rammelsberg, and the lenses may be laterally persistent for tens of kilometres. This may therefore indicate that the area is a distal part of a sequence occurring along strike from Sedex-type massive sulphide mineralisation.

C. An anomaly in the North Molton area (Figure 3) may represent geochemical anomalies relating to mines that were active until the $19^{\text {th }}$ century and worked a variety of ores including copper minerals, galena, sphalerite, siderite or haematite and sometimes barytes ${ }^{14}$.

D. The prospective area approximately $8 \mathrm{~km}$ south-west of Combe Martin is centred on a regional gravity and magnetic anomaly at West Down. This anomaly was verified by BGS ground magnetic surveys that indicated a positive anomaly of amplitude up to $250 \mathrm{nT}$ due to a body up to $100 \mathrm{~m}$ wide at a few tens of metres depth ${ }^{14}$. The gravity anomaly has since been confirmed by high-resolution gravity surveying which identified a positive anomaly of about $1 \mathrm{mGal}$ coincident with the magnetic anomaly ${ }^{8}$. The anomaly has not been tested by drilling but may represent disseminated pyrrhotite with remnant and induced magnetisation as identified from the drilling of a similar anomaly at Honeymead Farm.

\section{Conclusions}

1. Comparison of the geology and mineral deposits of the Iberian Pyrite Belt in Spain and Portugal with those in south-west England suggests potential for similar stratiform VMS zinc-copper-lead deposits in the (allochthonous) DevonianCarboniferous volcano-sedimentary sequence (VSC) in the Central Area of Devon and east Cornwall. Stratiform mineralisation is known to occur at three stratigraphical horizons and at over 60 sites in the East Cornwall-Devon project area. Economic mineralisation may be present in these horizons but available data does not provide clear targets for drilling.

2. By analogy with the geological setting and mineral deposits of the Harz Massif in Germany, there is potential in the Exmoor district of North Devon for the occurrence of sedimentary exhalative (Sedex) polymetallic (zinc-copper-leadsilver) mineralisation. Evidence from Combe Martin and from drilling at Honeymead Farm, approximately $25 \mathrm{~km}$ along strike, provides support for this hypothesis.

3. Weights of Evidence and Fuzzy Logic prospectivity analysis have been carried out over the two target areas on the basis of exploration models for IPB VMS and Sedex deposit types. This has involved the integration of multivariate geological, geophysical, geochemical and mineral occurrence data and has successfully identified several new targets for stratiform base-metal sulphide mineralisation. The main prospective areas are: (i) in the central region along the northern edges of 
Bodmin Moor and Dartmoor and in the intervening ground underlain by Lower Carboniferous strata; (ii) in the Upper Devonian and Lower Carboniferous rocks on Exmoor; (iii) in the Lower Carboniferous strata on the eastern side of Dartmoor.

4. Underpinning the evaluation of the area to the north of Bodmin Moor and Dartmoor is the assumption that the highfrequency magnetic anomalies present are primarily related to stratiform sulphide mineralisation within the FammenianVisean sequence subsequently recrystallised to pyrrhotite at the time of granite intrusion. Modelling of these data suggest shallow sources for these magnetic anomalies, and drilling has not tested most of these. The main uncertainty is that low concentrations of pyrrhotite can maintain a high NRM intensity so that large magnetic anomalies may be due to only a few per cent sulphide; however, this can only be determined through drilling.

\section{Acknowledgements}

This paper is published with the permission of the Director of the British Geological Survey (NERC). The authors would like to thank Tim Colman and Gus Gunn who helped in the preparation of this paper and provided useful comments and feedback.

\section{References}

$1 \quad$ P. An, W.M. Moon and A. Rencz: "Application of fuzzy set theory for integration of geological, geophysical and remote sensing data", Canadian Journal of Exploration Geophysics, 1991, 27, 1-11.

2 K.E. Beer, T.K. Ball, D.C. Cooper, A.D. Evans, R.C. Jones, K.E. Rollin and J.M.C. Tombs: "Mineral investigations in the Teign Valley, Devon. Part 2: base metals", Mineral Reconnaissance Programme Report of the British Geological Survey, No. 123,1992.

3 K.E. Beer and P.J. Fenning: "Geophysical anomalies and mineralisation at Sourton Tors, Okehampton, Devon", Report Institute of Geological Sciences, No 76/1,1976.

4 K.E. Beer, G.S. Kimbell and M. J. Bennett: "Skarn-type copper mineralisation in the vicinity of Belstone Consols Mine, Okehampton, Devon", Mineral Reconnaissance Programme Report of the British Geological Survey, No $101,1989$.

5 G.F. Bonham-Carter, "Geographical Information System for Geoscientists: Modelling with GIS",1994, Pergamon, London.

6 British Geological Survey: "Colour shaded relief gravity anomaly map of Britain, Ireland and adjacent areas", I.F. Smith and J.W.F. Edwards (compilers), British Geological Survey, 1:1 500000 Scale, Keyworth, Nottingham, United Kingdom, 1997.

$7 \quad$ British Geological Survey: "Colour shaded relief magnetic anomaly map of Britain, Ireland and adjacent areas." C.P. Royles and I.F. Smith (compilers), British Geological Survey, 1:1 500000 Scale, Keyworth, Nottingham, United Kingdom, 1998.

8 British Geological Survey: "Induced polarisation and high-resolution gravity surveys on Exmoor, SW England", British Geological Survey (unpublished data), 2004.

$9 \quad$ P. Claughton: "North Devon and Exmoor - Methodology for mining history research; identifying and maintaining the integrity of a fragile mining landscape",1997, [

http://www.exeter.ac.uk/ pfclaugh/mhinf/contents.htm\#south-west].

10 J.D. Cornwell: "The magnetisation of Lower Carboniferous rocks from the north-west border of the Dartmoor granite, Devonshire", Geophysical Journal of the Royal Astronomical Society, 1967, 12, 381-403. 

southern Portugal. Abstracts volume". GEODE meeting, Huelva, Spain, 2001, European Science Foundation 12 C. D'Ercole, D.I. Groves and C.M. Knox-Robinson: "Using fuzzy logic within a GIS-environment to enhance conceptually based prospectivity analysis of MVT mineralisation", Australian Journal of Earth Sciences, 2000, 47, 913927.

13 H.G. Dines, "The metalliferous mining region of south-west England", Memoir of the Geological Survey of Great Britain, 2 volumes,1956, HMSO, London.

14 E.A. Edmonds, A. Whittaker and B.J. Williams, "The geology of the country around Ilfracombe and Barnstaple", Memoir of the British Geological Survey, Sheets 277 and 293 (England and Wales),1985

15 D.I. Groves, R.J. Goldfarb, C.M. Knox-Robinson, J. Ojala, S. Gardoll, G.Y. Yun and P. Holyland: "Late kinematic timing of orogenic gold deposits and significance for computer-based exploration techniques with emphasis on the Yilgarn Block, Western Australia", Ore Geology Reviews, 2000, 17(1-2), 1-38.

16 R. Hazelton: "Egloskerry Drilling and Final Report - Egloskerry Lead-Zinc prospect", Mineral Exploration and Investment Grant Act (MEIGA) Report, British Geological Survey, No. 223,1983.

17 R.C. Jones, K.E. Beer and J.M.C. Tombs: "Geochemical and geophysical investigations in Exmoor and the Brendon Hills", Mineral Reconnaissance Programme Report of the British Geological Survey, No. 90,1987.

18 L.D. Kemp, G.F. Bonham-Carter, G.L. Raines and C.G. Looney: "Arc-SDM: Arcview extension for spatial data modelling using weights of evidence, logistic regression, fuzzy logic and neural network analysis",2001, [ http://ntserv.gis.nrcan.gc.ca/sdm/.].

19 D. Large and E. Walcher: "The Rammelsberg massive sulphide Cu-Zn-Pb-Ba deposit, Germany: an example of sediment-hosted, massive sulphide mineralisation", Mineralium Deposita, 1999, 34, 522-538.

20 R.C. Leake, D.G. Cameron, R.C. Scrivener and D.J. Bland: "Exploration for gold in the Crediton Trough, Devon. Part 2: detailed surveys", Mineral Reconnaissance Programme Report of the British Geological Survey, No. $134,1994$.

21 J.M. Leistel, E. Marcoux, D. Thieblemont, C. Quesada, A. Sanchez, G.R. Almodovar, E. Pasual and R. Sáez: "The volcanic-hosted massive sulphide deposits of the Iberian Pyrite Belt. Review and preface to the Thematic Issue", Mineralium Deposita, 1998, 33, 82-97.

22 D. MacIntyre: "Sedimentary Exhalative Zn-Pb-Ag", in: "Selected British Columbia Mineral Deposit Profiles", (eds. D.V. Lefebure and G.E. Ray), 1 - Metallics and Coal, 37-39; 1995, British Columbia Ministry of Energy of Employment and Investment Open File 1995-20.

23 M.C. McKeown, E.A. Edmonds, M. Williams, E.C. Freshney and D.J. Masson-Smith, "Geology of the Country around Boscastle and Holsworthy. Sheet 322-323", Memoirs of the Geological Survey of Great Britain,1973, HMSO, London.

24 J.T. Oliveira and C. Quesada: "A comparison of stratigraphy, structure and palaeogeography of the south Portugese Zone and Southwest England, European Variscides", Geoscience in south-west England, 1998, 9, $141-150$.

25 B.G. Rawlins, K. O'Donnell and M. Ingham: "Geochemical survey of the Tamar catchment (south-west England)", British Geological Survey, CR/03/027,2003.

26 J.M.S.R. Relvas, B.F.J.A. S, A. Pinto, A.F. Ferreira, N. Pacheco, P. Noiva, G. Barriga, R. Baptista, D. Carvalho, V. Oliveira, J. Munhá and R.W. Hutchinson: "The Neves Corvo deposit, Iberian Pyrite Belt, Portugal: impacts and future, 25 years after the discovery", Society of Economic Geologists Special Publications, 2002, 9, 155-176. 
A. Ribeiro, C. Quesada and R.D. Dallmeyer: "Gladinamic evolution of the Iberian Massif", in: "Pre-Mesozoic geology of Iberia", (eds. Dallmeyer and Martinez), 397-410; 1990, Springer, Berlin.

28 K.E. Rollin: "A detailed gravity survey between Dartmoor and Bodmin Moor: the shape of the Cornubian granite ridge and a new Tertiary basin", Proceedings of the Geologist's Association, 1988, 99, 15-25.

29 K.E. Rollin, A.G. Gunn, R.C. Scrivener and M.H. Shaw: "Potential for stratiform massive sulphide mineralisation in south-west England", DTI Minerals Programme Publication, British Geological Survey, CR/01/240,2001.

30 K.E. Rollin, M.H. Shaw, A.J. Benham and D.J.R. Morgan: "High Resolution gravity surveys at Egloskerry and Combe Martin, SW England", British Geological Survey Internal Report., IR/02/195, 2002.

31 R. Sáez, E. Pascual, M. Toscano and G.R. Almodóvar: "The Iberian type of volcano-sedimentary massive sulphide deposit", Mineralium Deposita, 1999, 34, 549-570.

32 R.C. Scrivener and M.J. Bennett: "Ore genesis and controls of mineralisation in the Upper Palaeozoic rocks of North Devon", Proceedings of the Ussher Society, 1980, 5, 54-58.

33 E.B. Selwood, E.M. Durrance and C.M. Bristow (Eds), "The Geology of Cornwall",1998, University of Exeter Press, Exeter.

34 E.B. Selwood, I.J. Stewart, P.J. Turner and M.J. Whiteley: "The Devonian-Carboniferous transition and its structural setting at Chillaton, West Devon, England", Geological Magazine, 1982, 119, 383-393.

35 M.H. Tangestani and F. Moore: "Comparison of three principal component analysis techniques to porphyry copper alteration mapping: a case study, Meiduk area, Kerman, Iran", Canadian Journal of Remote Sensing, 2001, 27, 176-182.

36 M.H. Tangestani and F. Moore: "Mapping porphyry copper potential with a fuzzy model, northern Shahr-eBabak, Iran", Australian Journal of Earth Sciences, 2003, 50(3), 311-317.

37 G.K. Taylor, D.M. Hake, I.R. King and B. R: "The Sourton Tors geophysical anomaly revisited", Geoscience in south-west England, 2001, 10, 166-171.

38 J.M.C. Tombs: "Results of a gravity survey of the south-west margin of Dartmoor, Devon", Mineral Reconnaissance Programme Report of the Institute of Geological Sciences, 34,1980.

39 F. Tornos, J. Locutura and L. Martins. "The Iberian Pyrite Belt Guide. Field trip B4". Joint SGA IAGOD International meeting, 1999, ITGE-IGM,pp. 49.

40 G. Venkataraman, B.B. Madhavan, D.S. Ratha, P.A. Joju, R.S. Goyal, S. Banglani and S.R. Sinha: "Spatial modelling for base-metal mineral exploration through integration of geological data sets", Natural Resources Research, 2000, 9 (no.1), 27-42.

41 H. Wang, G. Cai and Q. Cheng. "Data integration using weights of evidence model: Applications in mapping mineral resource potentials". Symposium on Geospatial Theory, Processing and Applications, Ottawa, Canada, 2002, ISPRS Commission IV 2002.

42 L. Wilkinson, J. Harris and B. Kjarsgaard. "Searching for Kimberlite: preliminary weights of evidence modeling of the Lac de Gras area, NWT, using GIS technology". International Conference on Applied Geologic Remote Sensing, 1999, I.263-I.270.

43 D.F. Wright and G.F. Bonham-Carter: "VHMS favourability mapping with GIS-based integration models, Chisel Lake-Anderson Lake area", in: "EXTECHI:A multidisciplinary approach to massive sulfide research in the Rusty 
Lake-Snow Lake greenstone belts, Manitoba", (eds. Bonham-Carter, Galley and Hall), Bulletin 426, 339-376; 1996, Geological Survey of Canada. 


\section{Figures}




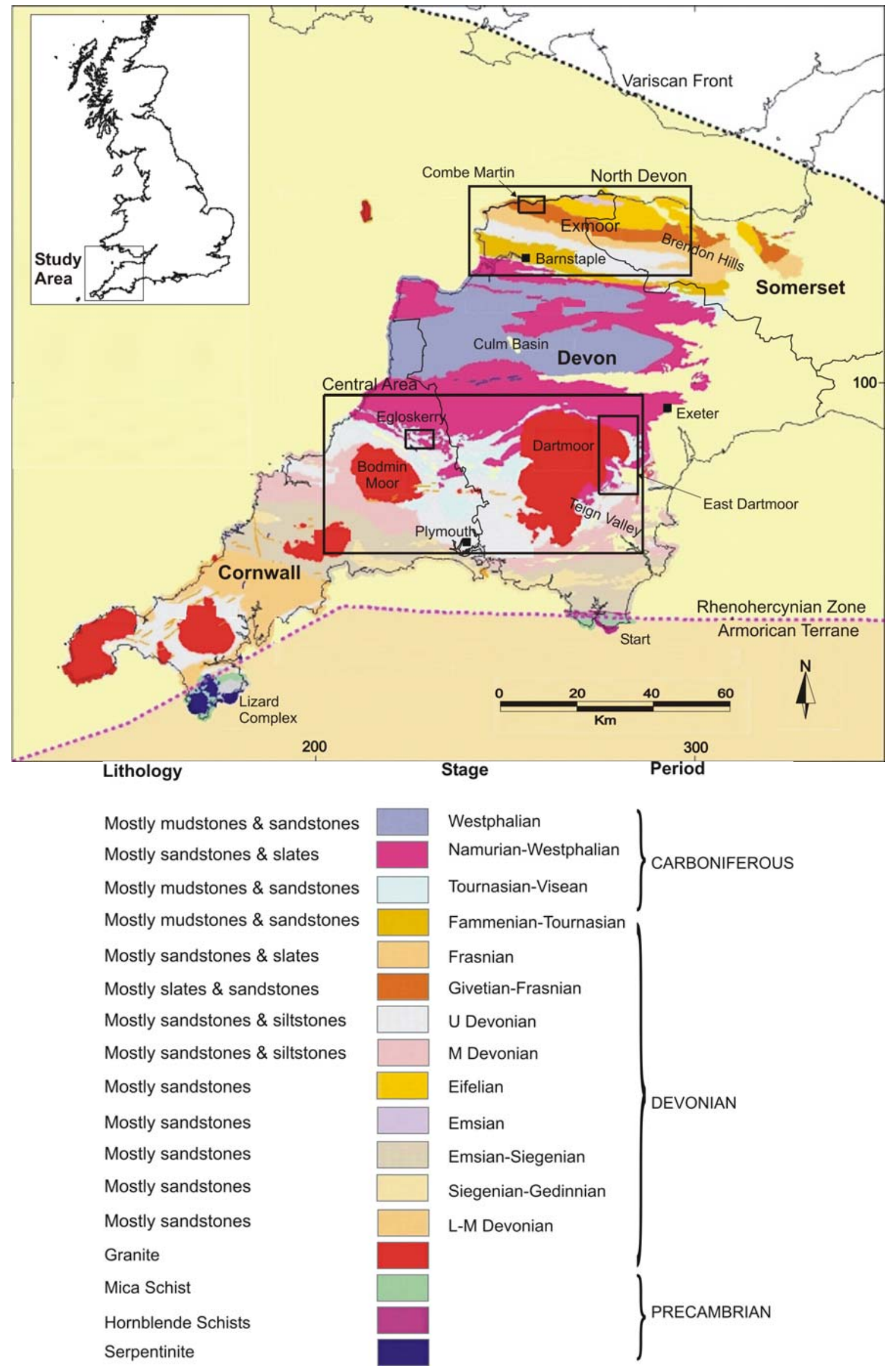

Figure 1. Simplified geology of south-west England and localities mentioned in the text. 


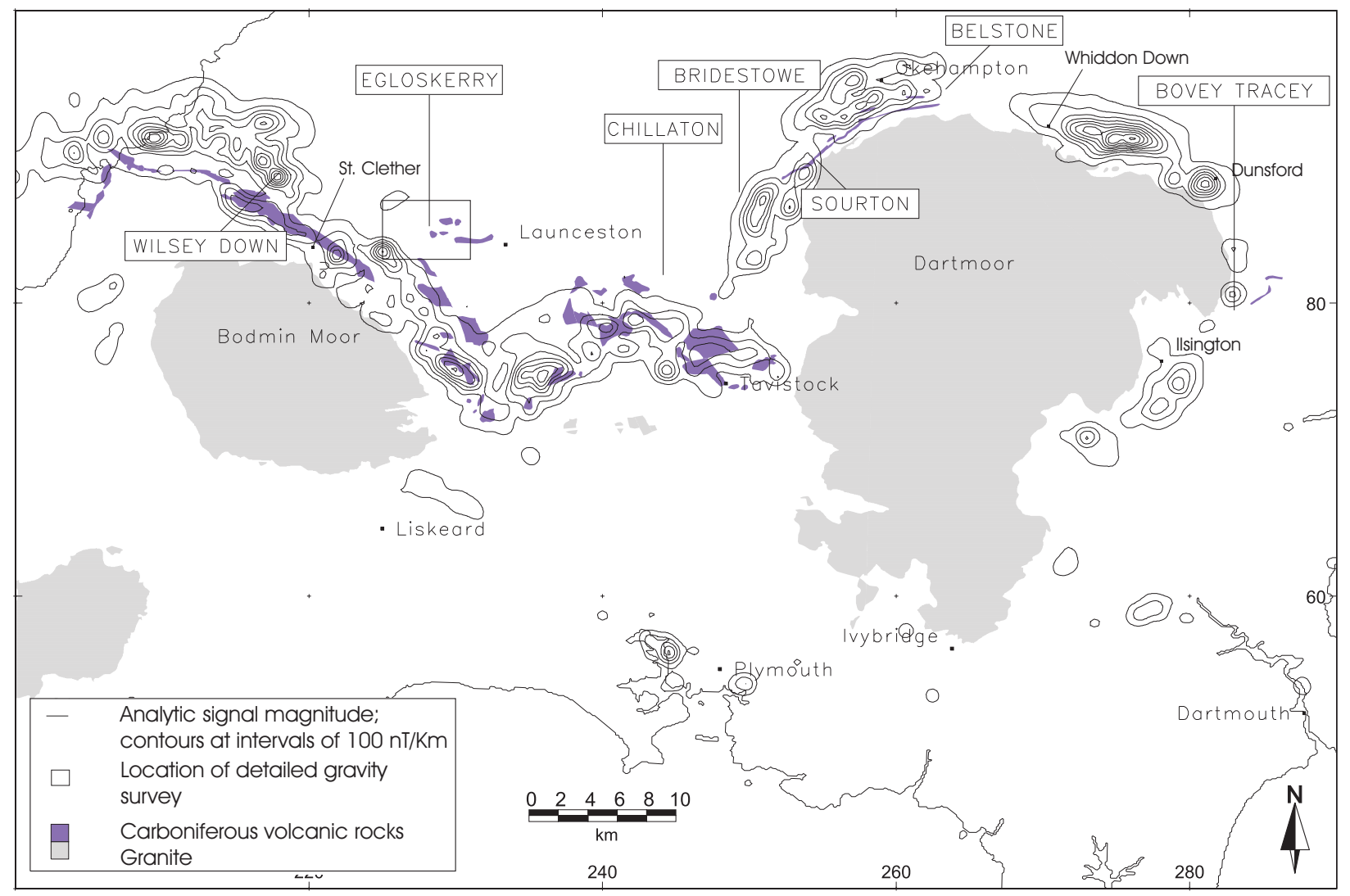

Figure 2. Location of the aeromagnetic analytic signal anomaly and the sites of previous investigations in the Central Area. 

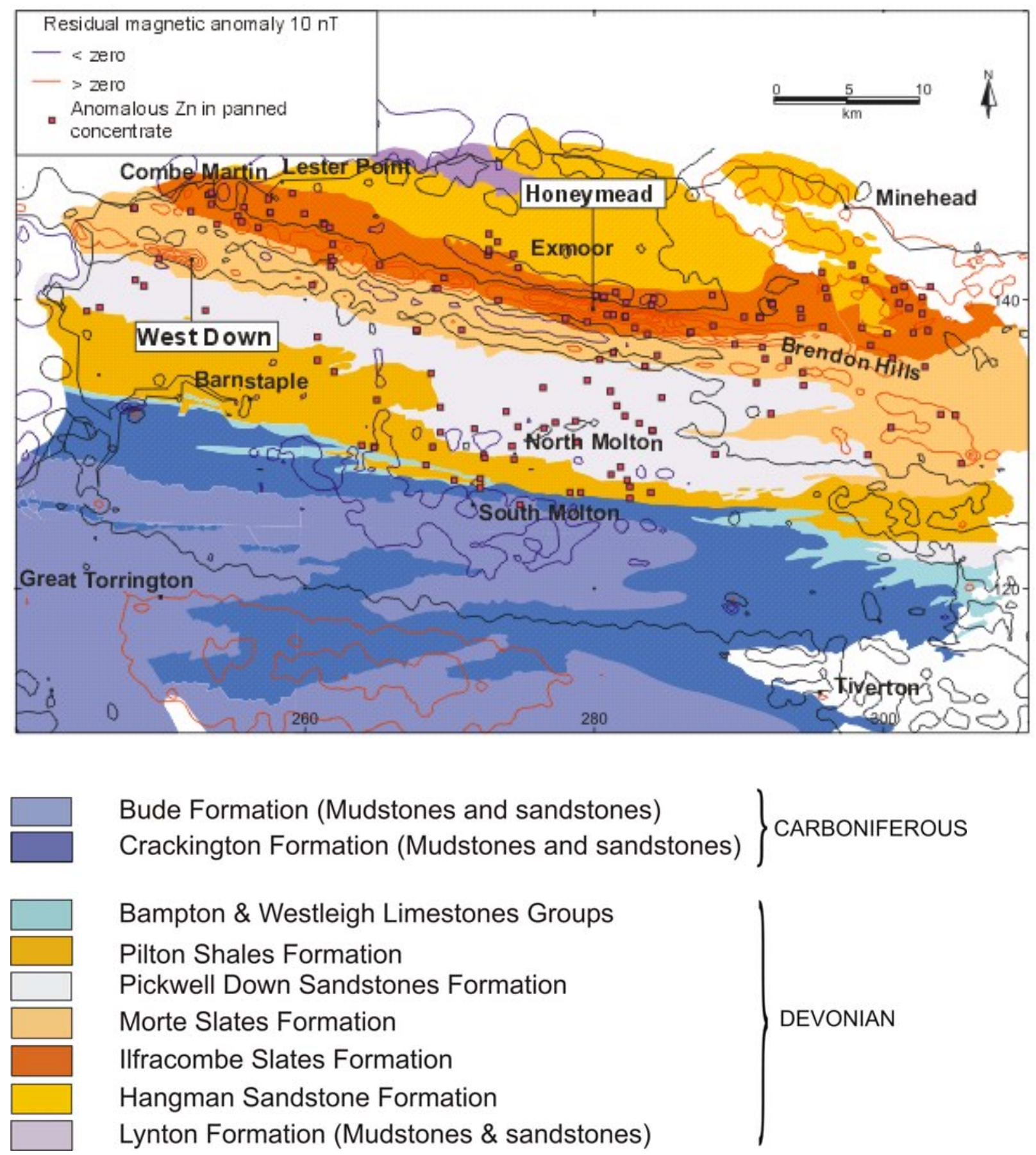

Bampton \& Westleigh Limestones Groups

Pilton Shales Formation

Pickwell Down Sandstones Formation

Morte Slates Formation

Ilfracombe Slates Formation

Hangman Sandstone Formation

Lynton Formation (Mudstones \& sandstones)

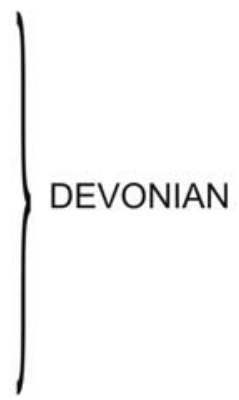

Figure 3. Location of previous exploration in North Devon and contours of the residual magnetic field. 


\begin{tabular}{|c|c|c|}
\hline \multirow{8}{*}{ 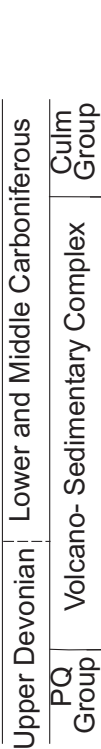 } & $\frac{\mathrm{IPB}}{\text { Lithostratigraphy }}$ & 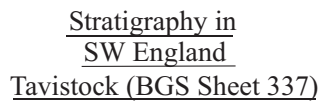 \\
\hline & Shales and litharenites & $\begin{array}{l}\text { Crackington } \\
\text { (shales, }\end{array}$ \\
\hline & $\begin{array}{l}\text { Basal Shaly Series } \\
\text { Flows, epiclastites \& conglomerates }\end{array}$ & sandstones) \\
\hline & $\begin{array}{l}\text { Purple shales } \\
\text { Shales and epiclastites } \\
\text { Fe and Mn jaspers/ chert } \\
\text { Lavas, breccias \& tuffs }\end{array}$ & $\begin{array}{l}\text { Meldon Chert } \\
\text { Greystone } \\
\text { Milton Abbot } \\
\text { (volcanics) }\end{array}$ \\
\hline & $\begin{array}{l}\text { Shales and tuffites } \\
\text { Basic lavas and spilites }\end{array}$ & $\begin{array}{l}\text { Tintagel } \\
\text { Volcanic } \\
\text { (tuffs) }\end{array}$ \\
\hline & Black shales, shales and tuffites & $\begin{array}{l}\text { Brendon } \\
\text { (mudstones) }\end{array}$ \\
\hline & $\begin{array}{l}\text { Rhyolitic flows and tuffs } \\
\text { Basic subvolcanic rocks (sills) }\end{array}$ & $\begin{array}{l}\text { Dolerite, } \\
\text { peridotite }\end{array}$ \\
\hline & $\begin{array}{l}\text { Shales, quartzites, conglomerates } \\
\& \text { litharenites with limestone lenses }\end{array}$ & $\begin{array}{l}\text { Tavy (silty } \\
\text { mudstone) }\end{array}$ \\
\hline
\end{tabular}

Figure 4. Stratigraphic comparison between the IPB and part of the Central Area. 


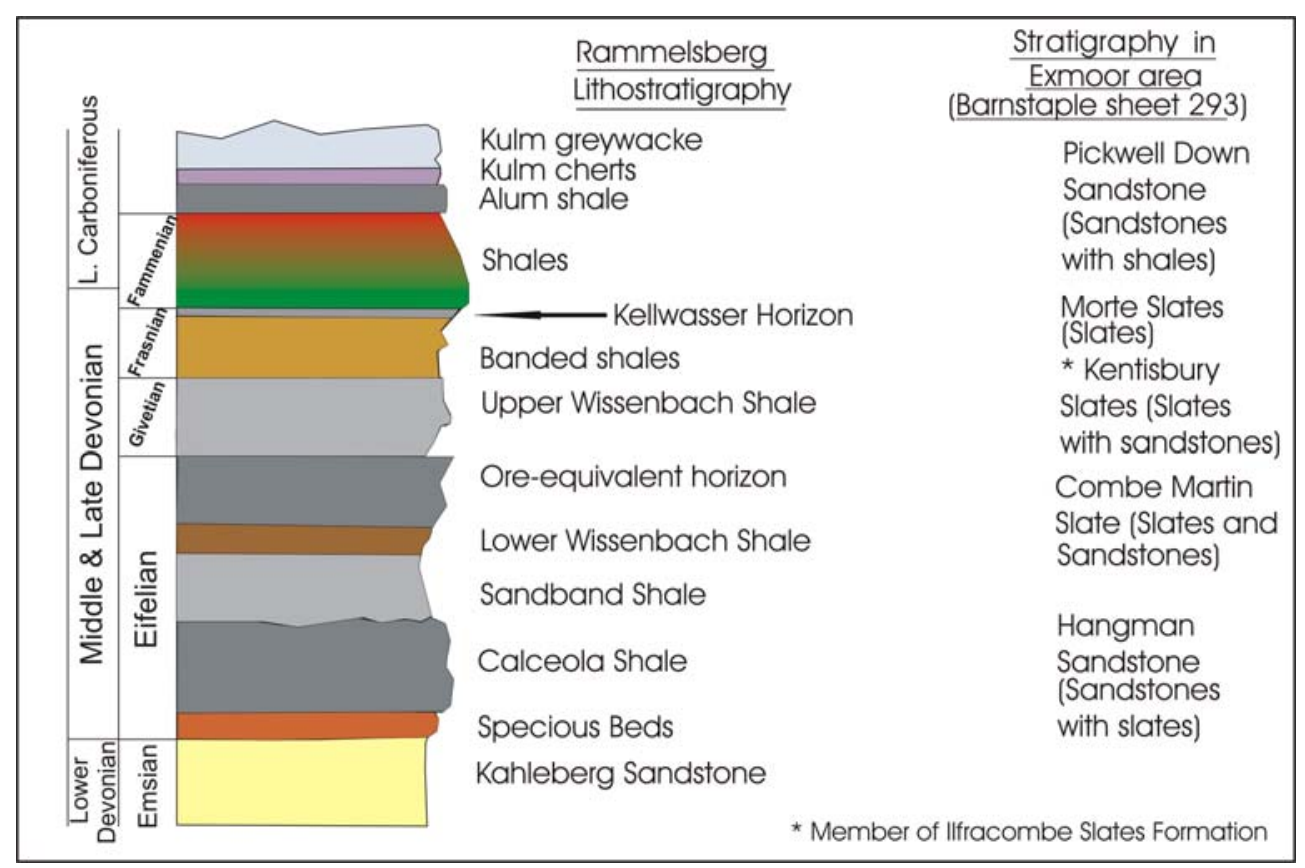

Figure 5. Stratigraphic comparison between the Rammelsberg deposit and part of the North Devon area. 


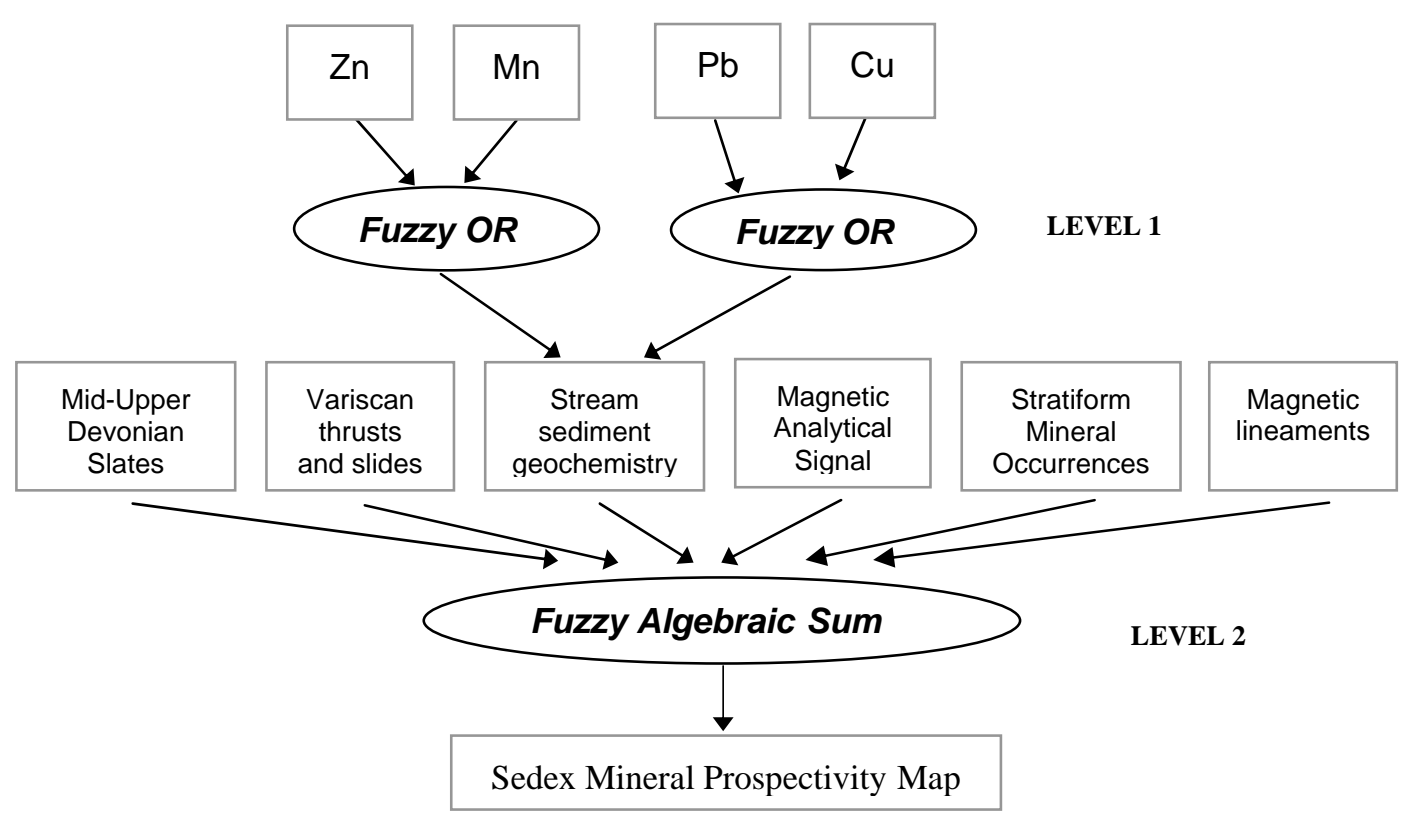

Figure 6. Schematic Fuzzy Logic model used for the North Devon area. 


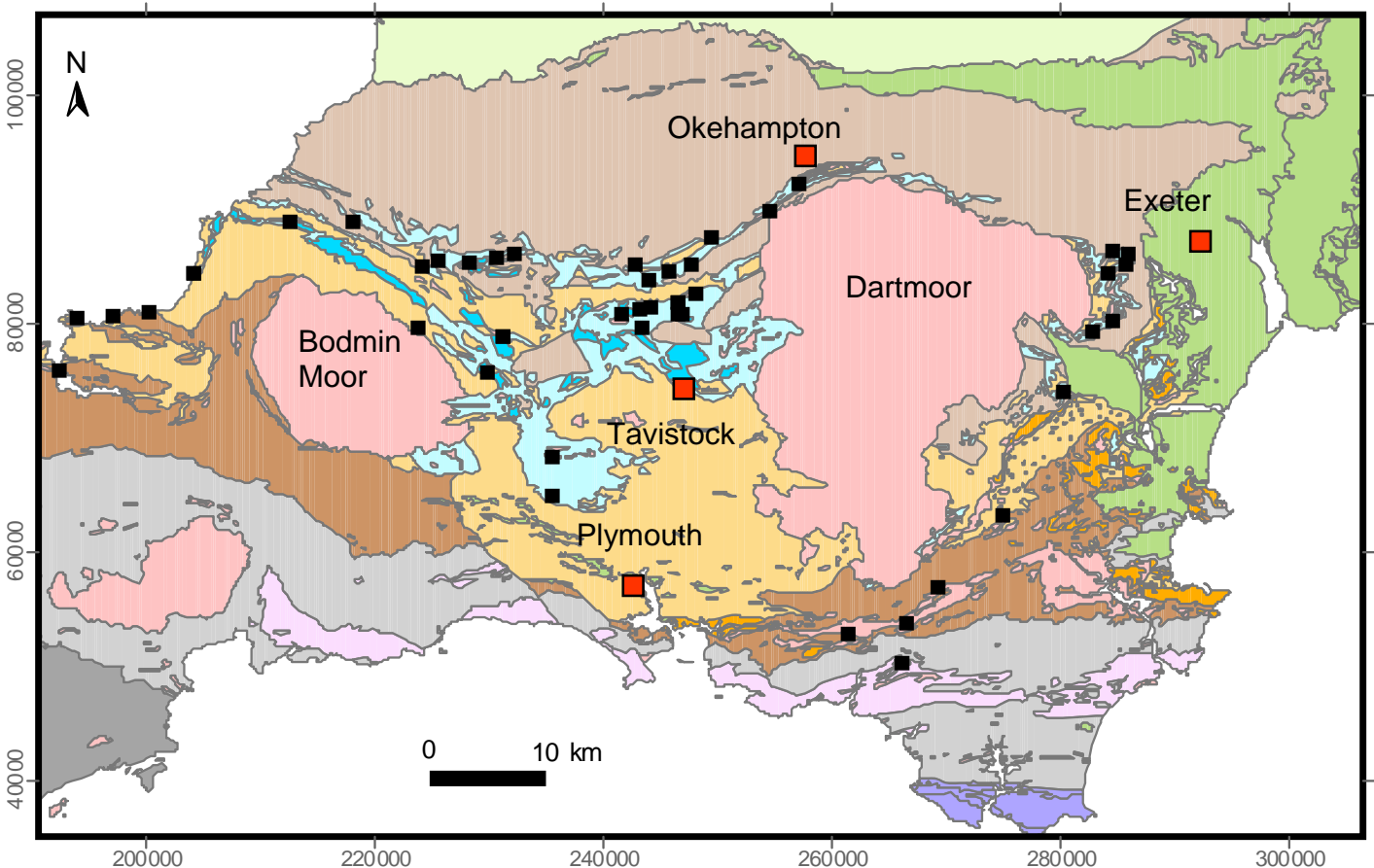

Figure 7. Simplified geological map of the Central Area showing the distribution of stratiform mineral occurrences.

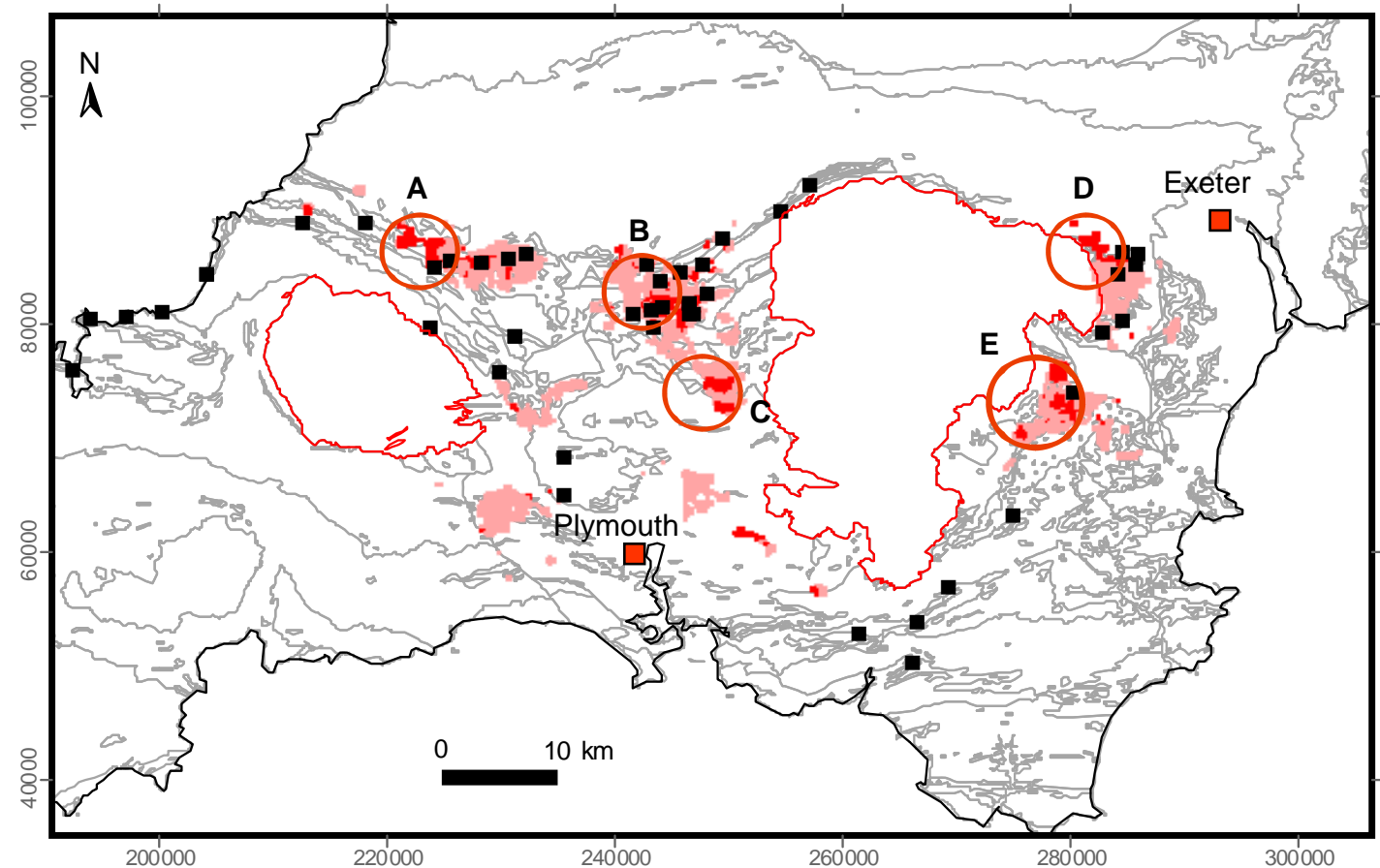

Figure 8. Prospectivity map for IPB-type deposits in the Central Area. Main targets identified A-E.

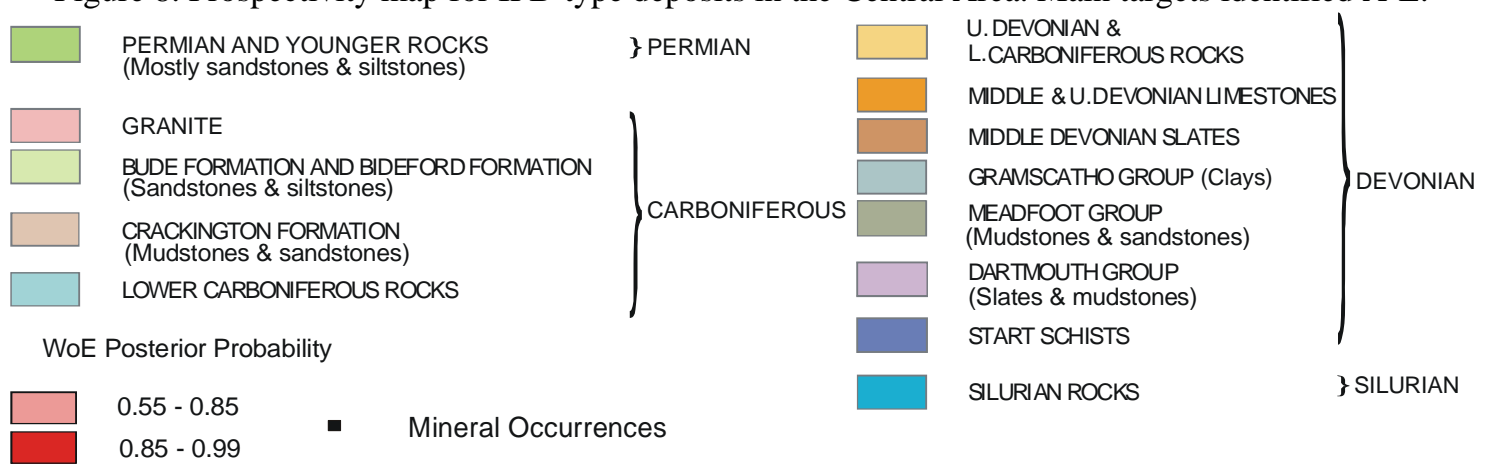




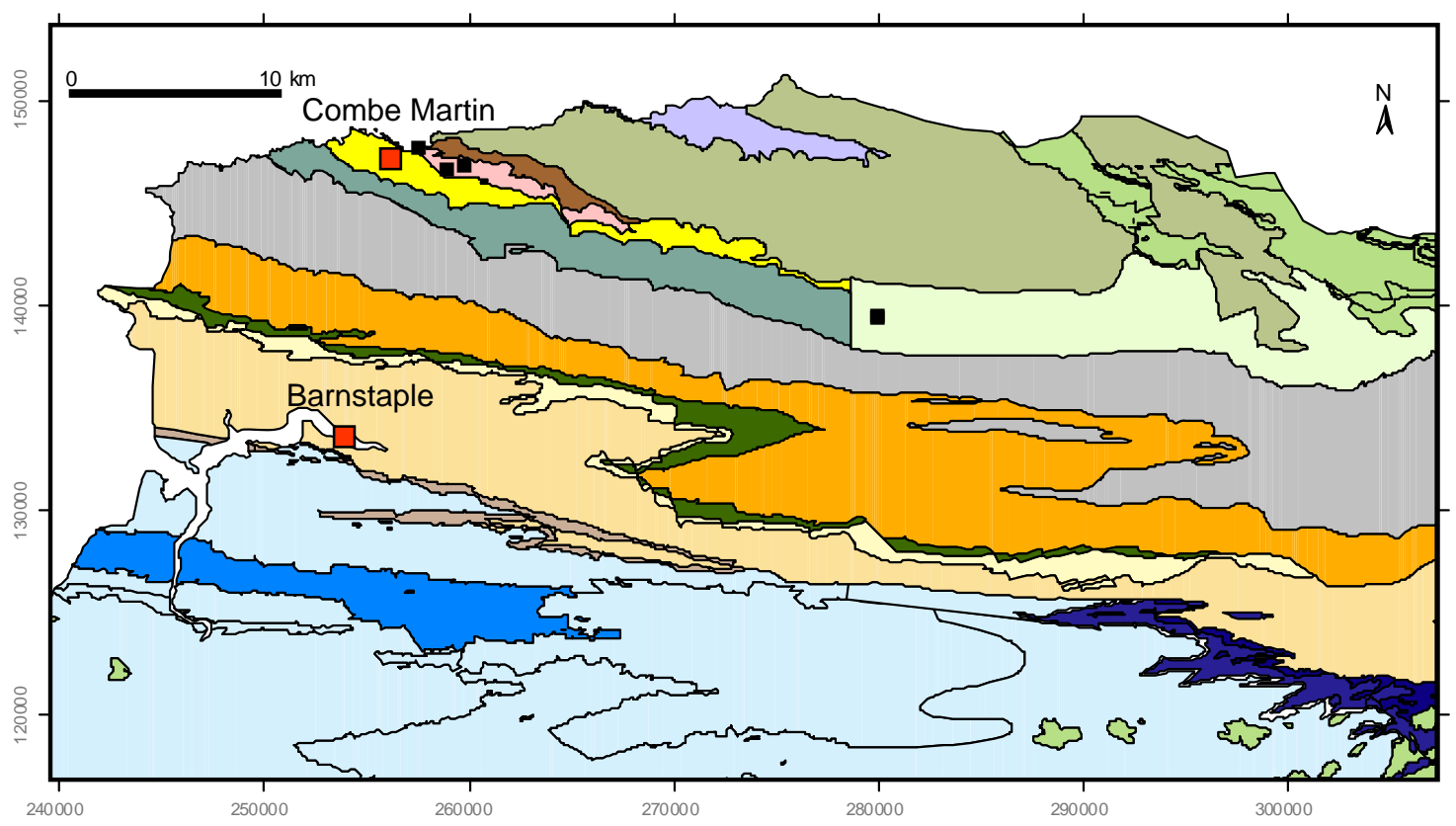

Figure 9. Simplified geological map of the North Devon area (note that the colour change within the Ilfracombe Slates Formation is due to variation in the detail of the mapping on adjacent 1: 50000 geological map sheets).

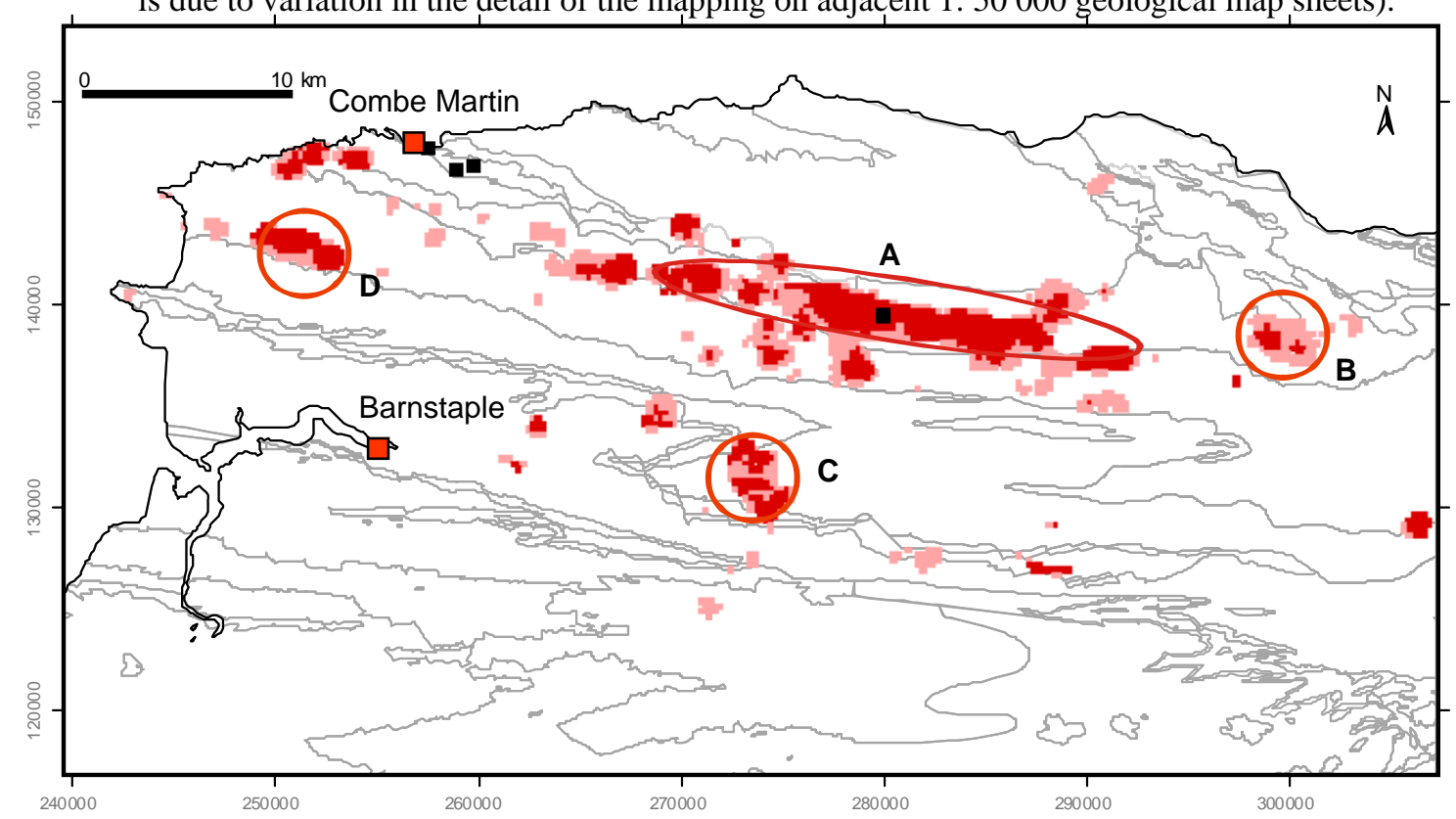

Figure 10. Prospectivity map for Sedex deposits in North Devon. Main targets identified A-D.

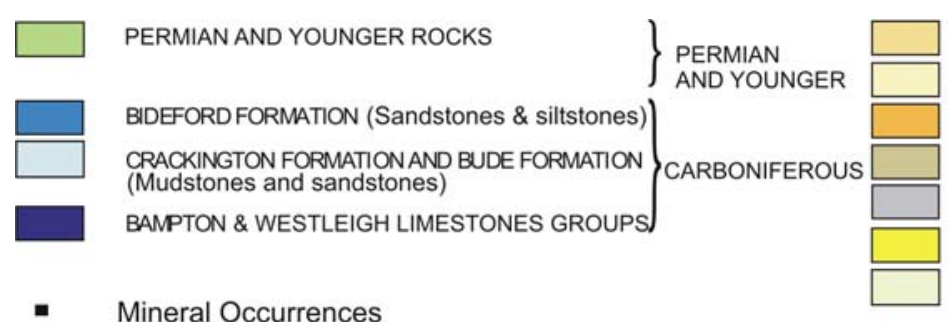

- Mineral Occurrences

Fuzzy Logic Prospectivity
Medium $(0.55-0.85)$
High $\quad(0.85-0.99)$

PLTONSHALES FORMATION BAGGY SANDSTONES FORMATION PICKWEU DOWN SANDSTONES FORMATION UPCOTT SLATES FORMATION MORTE SLATES FORMATION COMBE MARTIN SLATES MEMBER ILFRACOMBE SLATES FORMATION

KENTISBURY SLATES MEMBER $\left.\begin{array}{l}\text { LESTER SLATES AND SANDSTONES MEMBER } \\ \text { WLD PEAR SLATES MEMBER }\end{array}\right\}$ *

HANGMAN SANDSTONE FORMATION

LYNTONFORMATION (Mudstones \& sandstones)

* MEMBERS OF ILFRACOMBE SLATES FORMATION 
Tables 


\begin{tabular}{|c|c|c|}
\hline \multicolumn{3}{|l|}{ Central Area } \\
\hline Investigation & Details & Reference(s) \\
\hline Wilsey Down & $\begin{array}{l}\text { BGS borehole (1968) to test high-amplitude negative magnetic anomaly identified pyrrhotite from } \\
\text { 76-259 m possibly related to the recrystallisation of syngenetic pyrite. }\end{array}$ & 23 \\
\hline Egloskerry & $\begin{array}{c}\text { RioFinex carried out extensive soil and deep overburden sampling. Drilling (11 boreholes) identified } \\
\text { stratabound galena and minor sphalerite in Lower Carboniferous shales and mudstones associated } \\
\text { with anomalous Pb, Zn, Cu and Mn values. } \\
\text { BGS high resolution gravity survey. }\end{array}$ & 16,29 \\
\hline Chillaton & $\begin{array}{l}\text { MRP surveys over Lower Carboniferous strata included soil sampling, IP, SP and VLF. Pyritiferous } \\
\text { black shales in two boreholes enriched in Mo and As but not base-metals. }\end{array}$ & 20,34 \\
\hline Bridestowe & $\begin{array}{l}\text { RioFinex survey (1981-82) identified } \mathrm{Pb} \text { and } \mathrm{Zn} \text { anomalies in soil and overburden. Three boreholes } \\
\text { (aggregate length } 371 \mathrm{~m} \text { ) with minor } \mathrm{Cu}, \mathrm{Pb} \text { and } \mathrm{Zn} \text { enrichment. }\end{array}$ & 16 \\
\hline Sourton & $\begin{array}{c}\text { Seven MRP boreholes with up to } 8.8 \% \text { by weight pyrrhotite in Carboniferous chert formations. No } \\
\text { Cu or Zn enrichment. }\end{array}$ & 3, 37 \\
\hline Belstone & MRP soil sampling and four boreholes encountered minor $\mathrm{Cu}, \mathrm{Zn}$ and As anomalies in chert units. & 4 \\
\hline Bovey Tracey & $\begin{array}{l}\text { Four MRP boreholes to test soil and IP anomalies. Discontinuous stratabound sulphides with a } \\
\text { maximum of } 2 \% \mathrm{Zn} \text { over } 3 \mathrm{~m} \text {. Maximum } 0.2 \% \mathrm{~Pb} \text { and } 0.14 \% \mathrm{Cu} \text { over } 1 \mathrm{~m} \text {. }\end{array}$ & 2 \\
\hline \multicolumn{3}{|l|}{ North Devon } \\
\hline Honeymead & Two boreholes drilled to test magnetic anomaly intersected pyrrhotite mineralisation. & 14 \\
\hline Exmoor area & $\begin{array}{l}\text { MRP drainage geochemical survey in mid-late 1980s identified anomalous metal concentrations, } \\
\text { possibly stratiform related. }\end{array}$ & 17 \\
\hline SW England & $\begin{array}{l}\text { Two aeromagnetic surveys (1957 and 1960) identified two high frequency anomalies; an ESE-WNW } \\
\text { trending anomaly in the Exmoor area, and a strong residual magnetic anomaly to the north of the } \\
\text { Bodmin Moor and Dartmoor granites. Both may be syngenetic pyrite altered to pyrrhotite. }\end{array}$ & 7 \\
\hline
\end{tabular}

Table 1 . Summary of previous mineral exploration in both study areas. 


\begin{tabular}{|c|c|c|c|}
\hline Criteria & Type & Significance & $\begin{array}{l}\text { Present in } \\
\text { project } \\
\text { area }\end{array}$ \\
\hline $\begin{array}{l}\text { Extrusive bimodal felsic-mafic volcanic rocks aligned on productive } \\
\text { lineaments defined by acid volcanic rocks }\end{array}$ & $\mathrm{E}$ & $\mathrm{h}$ & Yes \\
\hline Devonian-Carboniferous VSC & $\mathrm{E}$ & $\mathrm{h}$ & Yes \\
\hline Sub-volcanic sill complex & $\mathrm{E}$ & $\mathrm{h}$ & Yes \\
\hline $\begin{array}{l}\text { Purple shales passing laterally into black shales close to the sulphide } \\
\text { deposits }\end{array}$ & $\mathrm{E}$ & h & Yes \\
\hline Extrusive spilitic rocks located close to, or within, the deposits. & $\mathrm{E}$ & $\mathrm{h}$ & Yes \\
\hline Co Bi geochemical anomalies & $\mathrm{C}$ & 1 & Yes \\
\hline Hydrothermal alteration (chloritisation) & $\mathrm{C}$ & l & $\begin{array}{c}\text { Not } \\
\text { known }\end{array}$ \\
\hline Active north-east trending early Carboniferous faults & $\mathrm{C}$ & l & $\begin{array}{c}\text { Not } \\
\text { known }\end{array}$ \\
\hline $\begin{array}{l}\text { Presence of massive pyroclastic rocks and tuff-breccias. Sulphide deposits } \\
\text { typically form within } 1000 \mathrm{~m} \text { of local acid volcanic centres }\end{array}$ & $\mathrm{C}$ & $\mathrm{m}$ & $\begin{array}{c}\text { Not } \\
\text { known }\end{array}$ \\
\hline Volcanic lineaments & $\mathrm{C}$ & $\mathrm{h}$ & $\begin{array}{c}\text { Not } \\
\text { known }\end{array}$ \\
\hline Visible pyrite within Fe-rich jaspers & $\mathrm{C}$ & $\mathrm{m}$ & $\begin{array}{c}\text { Not } \\
\text { known }\end{array}$ \\
\hline $\begin{array}{l}\text { Presence of isoclinal synclines adjacent to thrusts. Deposits usually occur in } \\
\text { thrust-bound overturned tight isoclinal folds showing rapid, major changes } \\
\text { in axial plunge }\end{array}$ & $\mathrm{C}$ & $\mathrm{m}$ & $\begin{array}{c}\text { Not } \\
\text { known }\end{array}$ \\
\hline $\begin{array}{l}\text { Residual gravity anomalies. Massive pyrite orebodies commonly have } \\
\text { strong resistivity and density contrasts with their host rocks }\end{array}$ & $\mathrm{C}$ & $\mathrm{h}$ & Yes \\
\hline IP or resistivity anomalies & $\mathrm{C}$ & $\mathrm{h}$ & Yes \\
\hline Mineral deposits or occurrences & $\mathrm{C}$ & $\mathrm{h}$ & Yes \\
\hline
\end{tabular}

Table 2. Key exploration criteria for IPB deposits and their occurrence in south-west England.

$\mathrm{E}=$ essential, $\mathrm{C}=$ characteristic. Significance: $\mathrm{h}=$ high, $\mathrm{m}=$ medium, $\mathrm{l}=$ low . 


\begin{tabular}{|l|c|c|c|}
\hline \multicolumn{1}{|c|}{ Criteria } & Type & Significance & Present in project area \\
\hline Rhenohercynian zone of the Variscan orogeny & E & h & Yes \\
\hline Middle Devonian post-rift shale & E & h & Yes \\
\hline Marginal structures to rifted basin & E & h & Not known \\
\hline Diabase sills in trough facies & E & l & Not known \\
\hline Low energy sedimentology & E & h & Yes \\
\hline Debris flow and sediment deformation & C & l & Not known \\
\hline Cross-cutting mineralisation with alteration & C & l & Not known \\
\hline Steep isoclinal folds & C & l & Not known \\
\hline Zn, Pb, Ba regional geochemical anomalies & C & h & Not known \\
\hline Sb, As, Co, Bi geochemical anomalies & C & m & Not known \\
\hline Associated minor zinc-lead vein system & C & m & Yes \\
\hline Sedex-type mineral occurrences & C & h & Yes \\
\hline EM or magnetic anomalies & C & h & Yes \\
\hline
\end{tabular}

Table 3. Key exploration criteria for Sedex deposits in Middle Devonian shales and slates in relation to North Devon. $\mathrm{E}=$ essential, $\mathrm{C}=$ characteristic. Significance: $\mathrm{h}=$ high, $\mathrm{m}=$ medium, $\mathrm{l}=$ low . 


\begin{tabular}{|c|c|c|}
\hline CRITERIA & IMPORTANT FEATURE & DATA SOURCE \\
\hline $\begin{array}{l}\text { Mineralisation in black } \\
\text { shales }\end{array}$ & $\begin{array}{c}\text { IPB sulphide mineralisation primarily hosted in } \\
\text { black shale horizons and associated with, or } \\
\text { capped by, chert horizons }\end{array}$ & $\begin{array}{c}\text { Chrono- and lithostratigraphy: 1:50 } 000 \text { digital } \\
\text { geological mapping }\end{array}$ \\
\hline $\begin{array}{l}\text { Spatially related to felsic } \\
\text { igneous rocks }\end{array}$ & $\begin{array}{l}\text { Mineralisation strongly associated with bimodal } \\
\text { felsic-mafic volcanic rocks }\end{array}$ & $\begin{array}{c}\text { Chrono- and lithostratigraphy: 1:50 } 000 \text { digital } \\
\text { geological mapping }\end{array}$ \\
\hline $\begin{array}{l}\text { Preferred structures: } \\
\text { major Variscan thrusts } \\
\text { and slides }\end{array}$ & $\begin{array}{l}\text { NNW-SSE lineaments, potentially related to } \\
\text { Variscan orogeny may be the most important } \\
\text { structures for IPB mineralisation }\end{array}$ & $\begin{array}{c}\text { 1:250,000 mapped faults, filtered to retain } \\
\text { NNW-SSE and NNE-SSW Variscan-related } \\
\text { structures }\end{array}$ \\
\hline $\begin{array}{l}\text { Proximity to major } \\
\text { thrusts/structures }\end{array}$ & $\begin{array}{l}\text { Mineralisation strongly associated with, or } \\
\text { adjacent to, major thrusts (inversion of } \\
\text { synsedimentary extensional faults?) }\end{array}$ & $\begin{array}{l}\text { Euclidean distance from filtered mapped } \\
\text { 1:250,000 faults }\end{array}$ \\
\hline $\begin{array}{l}\text { Geochemical anomalies } \\
\text { for } \mathrm{Zn}, \mathrm{Pb}, \mathrm{Cu}, \mathrm{Ba} \text { and } \\
\mathrm{Mn}\end{array}$ & Indicator of proximity to mineralisation & $\begin{array}{l}\text { Regional stream-sediment analyses: } 2006 \text { sites } \\
\text { from BGS Geochemical Database }\end{array}$ \\
\hline $\begin{array}{l}\text { Syngenetic pyrite } \\
\text { mineralisation }\end{array}$ & $\begin{array}{c}\text { Massive pyrite orebodies commonly have } \\
\text { marked density contrasts with their host rocks }\end{array}$ & UK gravity database: residual anomaly \\
\hline Magnetic mineralisation & $\begin{array}{l}\text { Indicative of magnetic pyrrhotite and/or } \\
\text { primary stratiform sulphide mineralisation }\end{array}$ & $\begin{array}{l}\text { UK Aeromagnetic database. Analytic signal } \\
\text { magnitude derived from residual anomaly }\end{array}$ \\
\hline $\begin{array}{l}\text { Proximity to major } \\
\text { basement lineaments }\end{array}$ & $\begin{array}{l}\text { Crustal structure, potentially important zones } \\
\text { for fluid transport and mineralisation }\end{array}$ & $\begin{array}{l}\text { UK gravity/magnetic database: lineaments } \\
\text { picked from shaded relief images of the } \\
\text { gravity/magnetic data. }\end{array}$ \\
\hline $\begin{array}{l}\text { Known metalliferous } \\
\text { mineralisation }\end{array}$ & Training point dataset & $\begin{array}{l}\text { Mineral occurrence data extracted from the UK } \\
\text { MOD Database and published occurrences }\end{array}$ \\
\hline
\end{tabular}

Table 4. Main exploration criteria for IPB deposits acquired from available datasets in south-west England. 


\begin{tabular}{|l|c|}
\hline \multicolumn{1}{|c|}{ EVIDENTIAL THEME } & CONTRAST \\
\hline Lithological units: shales and cherts horizons & 4.956 \\
\hline Proximity to anomalous Mn in stream sediment & 2.916 \\
\hline Proximity to mapped regional structure & 2.472 \\
\hline Proximity to anomalous Zn in stream sediment & 1.884 \\
\hline Proximity to anomalous Ba in stream sediment & 1.733 \\
\hline Proximity to anomalous Cu in stream sediment & 1.623 \\
\hline Proximity to anomalous Pb in stream sediment & 1.429 \\
\hline Lithological units: bimodal volcanics & 1.412 \\
\hline Proximity to anomalous magnetic analytical signal & 1.392 \\
\hline Proximity to anomalous magnetic residual anomalies & 0.884 \\
\hline Proximity to gravity residual anomalies & 0.872 \\
\hline
\end{tabular}

Table 5. Key predictive factors, by contrasts, determined for IPB mineralisation in the Central Area. 


\begin{tabular}{|c|c|c|}
\hline Criteria & Fuzzy membership values (range) & Details of weight \\
\hline $\begin{array}{l}\text { Prospective host lithologies } \\
\text { (shales and sandstones) }\end{array}$ & 0.7. No & $\begin{array}{c}0.7 \text { applied to selected Middle-Upper Devonian } \\
\text { lithologies }\end{array}$ \\
\hline $\begin{array}{l}\text { Analytical signal of } \\
\text { magnetic anomaly }\end{array}$ & $0.5(>90)$ to $0.1(>35)$ & \begin{tabular}{|c|} 
Incremental memberships from $>35$ (threshold) to \\
115 (max. value). Counts $<35$ assigned 0 .
\end{tabular} \\
\hline Zn in stream sediment & 0.6 (>2.5 std) to 0.1 (mean, $161 \mathrm{ppm})$ & \multirow{4}{*}{$\begin{array}{c}\text { Values }>\text { mean are increased by } 0.1 \text { for every } 1 / 4 \\
\text { standard deviation increment. Values }>2.5 \text { standard } \\
\text { deviation }=0.6\end{array}$} \\
\hline $\mathrm{Pb}$ in stream sediment & 0.6 (>2.5 std) to 0.1 (mean, $40 \mathrm{ppm})$ & \\
\hline $\mathrm{Cu}$ in stream sediment & 0.6 (>2.5 std) to 0.1 (mean, $20 \mathrm{ppm})$ & \\
\hline Mn in stream sediment & 0.6 (>2.5 std) to 0.1 (mean, $1530 \mathrm{ppm})$ & \\
\hline
\end{tabular}

Table 6. Fuzzy membership values assigned to each class within each non-point map. 


\begin{tabular}{|c|c|c|c|c|c|c|}
\hline \multirow{2}{*}{\begin{tabular}{|l|} 
Criteria \\
Buffer distance $(\mathrm{km})$ \\
\end{tabular}} & & & & & & \\
\hline & $0.0-0.5$ & $0.5-1.0$ & $1.0-1.5$ & $1.5-2.0$ & $2.0-2.5$ & $2.5-3.0$ \\
\hline & \multicolumn{6}{|c|}{ Fuzzy membership values (between 0 and 1 ) } \\
\hline $\begin{array}{l}\text { Variscan thrusts \& } \\
\text { slides (E-W) }\end{array}$ & 0.2 & 0.1 & 0.1 & 0 & 0 & 0 \\
\hline $\begin{array}{l}\text { Gravity and magnetic } \\
\text { Lineaments }\end{array}$ & 0.2 & 0.2 & 0.1 & 0.1 & 0 & 0 \\
\hline Mineral occurrences & 0.5 & 0.4 & 0.3 & 0.2 & 0.1 & 0 \\
\hline
\end{tabular}

Table 7. Fuzzy membership values (between 0 and 1 ) given to each buffer within each map (point or linear themes). 


\begin{tabular}{|c|c|c|c|c|c|c|}
\hline & & $\begin{array}{c}\text { A } \\
\text { N Bodmin } \\
\text { Moor }\end{array}$ & $\begin{array}{c}\text { B } \\
\text { Chillaton }\end{array}$ & $\begin{array}{c}\text { C } \\
\text { Tavistock }\end{array}$ & $\begin{array}{c}\text { D } \\
\text { Dunsford }\end{array}$ & $\begin{array}{c}\mathrm{E} \\
\text { Ilsington }\end{array}$ \\
\hline \multicolumn{2}{|l|}{ Extent $\left(\mathrm{km}^{2}\right)$} & 78 & 136 & 36 & 20 & 56 \\
\hline \multirow[t]{3}{*}{ Geology } & $\begin{array}{l}\text { Chert } \\
\text { Formations }\end{array}$ & $\begin{array}{c}\text { Fire Beacon } \\
\text { Chert } \\
\text { Meldon Chert } \\
\end{array}$ & $\begin{array}{l}\text { Fire Beacon } \\
\text { Chert }\end{array}$ & $\begin{array}{c}\text { Fire Beacon } \\
\text { Chert }\end{array}$ & $\begin{array}{l}\text { Teign } \\
\text { Chert }\end{array}$ & $\begin{array}{c}\text { Mount } \\
\text { Ararat Chert }\end{array}$ \\
\hline & $\begin{array}{l}\text { Shale } \\
\text { Formations }\end{array}$ & Many & Many & Many & Many & Many \\
\hline & $\begin{array}{l}\text { Volcanic } \\
\text { Formations }\end{array}$ & $\begin{array}{c}\text { Devonian to } \\
\text { Carboniferous } \\
\text { intrusives and } \\
\text { extrusives }\end{array}$ & $\begin{array}{c}\text { Devonian to } \\
\text { Carboniferous } \\
\text { extrusives }\end{array}$ & $\begin{array}{c}\text { Devonian to } \\
\text { Carboniferous } \\
\text { extrusives }\end{array}$ & $\begin{array}{l}\text { Minor } \\
\text { intrusive } \\
\text { suite }\end{array}$ & $\begin{array}{l}\text { Fowley Tuff } \\
\text { Formation } \\
\text { \& Devonian } \\
\text { volcanics }\end{array}$ \\
\hline \multicolumn{2}{|c|}{ Base metal occurrences } & $\begin{array}{c}4(\mathrm{Mn}) \\
1(\mathrm{~Pb} / \mathrm{Zn})\end{array}$ & $\begin{array}{l}13(\mathrm{Mn}), 1 \\
(\mathrm{Cu} / \mathrm{Pb} / \mathrm{Zn})\end{array}$ & 0 & $4(\mathrm{Mn})$ & $1(\mathrm{Mn})$ \\
\hline \multirow{4}{*}{$\begin{array}{l}\text { Geochemistry } \\
\text { (Max. ppm) }\end{array}$} & $\mathrm{Zn}$ & 502 & 380 & 250 & 4000 & 316 \\
\hline & $\mathrm{Pb}$ & 170 & 250 & 100 & 2100 & 1000 \\
\hline & $\mathrm{Cu}$ & 137 & 470 & 85 & 180 & 185 \\
\hline & $\mathrm{Mn}$ & 18000 & 32000 & 7500 & 10000 & 6181 \\
\hline \multicolumn{2}{|c|}{ Residual gravity (max. mGal) } & 2.1 & 2.1 & -1.5 & 2.6 & 2.2 \\
\hline \multicolumn{2}{|c|}{ Residual magnetics (max. nT) } & 235 & 286 & No & No & 127 \\
\hline \multicolumn{2}{|c|}{$\begin{array}{l}\text { Magnetic analytic signal } \\
(\mathrm{max} . \mathrm{nT} / \mathrm{km})\end{array}$} & 350 & 371 & 200 & 795 & 525 \\
\hline \multicolumn{2}{|c|}{ Structure: no. of E-W faults } & 14 & 5 & 2 & 1 & 3 \\
\hline
\end{tabular}

Table 8. Key features of the principal IPB targets in the Central Area (as shown in Figure 9). 


\begin{tabular}{|c|c|c|c|c|c|}
\hline \multirow{2}{*}{\multicolumn{2}{|c|}{\begin{tabular}{|l} 
\\
Extent $\left(\mathrm{km}^{2}\right)$
\end{tabular}}} & $\mathbf{A}$ & $\mathbf{B}$ & $\mathbf{C}$ & $\mathbf{D}$ \\
\hline & & 150 & 14 & 17 & 12 \\
\hline \multirow[t]{5}{*}{ Geology } & \multirow[t]{4}{*}{ Slate Formations } & Ilfracombe & \multirow{4}{*}{$\begin{array}{l}\text { Ilfracombe } \\
\text { (Major) }\end{array}$} & \multirow{4}{*}{$\begin{array}{l}\text { Upcott } \\
\text { (Minor) }\end{array}$} & \multirow[t]{4}{*}{ Morte } \\
\hline & & Morte & & & \\
\hline & & Kentisbury & & & \\
\hline & & Combe Martin & & & \\
\hline & \begin{tabular}{|l} 
Sandstone \\
Formations
\end{tabular} & No & $\begin{array}{l}\text { Hangman } \\
\text { (Minor) }\end{array}$ & $\begin{array}{c}\text { Pickwell } \\
\text { Down (Major) }\end{array}$ & No \\
\hline \multicolumn{2}{|c|}{ Stratiform mineral occurrences } & $\begin{array}{c}1 \text { borehole occurrence } \\
\text { (Honeymead Farm) }\end{array}$ & None known & None known & None known \\
\hline \multirow{4}{*}{$\begin{array}{l}\text { Geochemistry } \\
\text { (max. value in } \\
\text { ppm) }\end{array}$} & $\mathrm{Cu}$ & 110 & 95 & 300 & 30 \\
\hline & $\mathrm{Mn}$ & 16700 & 5138 & 4399 & 1754 \\
\hline & $\mathrm{Pb}$ & 460 & 190 & 30 & 80 \\
\hline & $\mathrm{Zn}$ & 800 & 1600 & 120 & 240 \\
\hline \multicolumn{2}{|c|}{ Number of aeromagnetic lineaments } & 5 & 2 & 3 & No \\
\hline \multicolumn{2}{|c|}{ Magnetic Analytical Signal (nT/km) } & 114 & 11 & 23 & 113 \\
\hline \multicolumn{2}{|c|}{ Number of Variscan thrusts and faults } & 4 & No & 1 & 1 \\
\hline
\end{tabular}

Table 9. Key features of the principal Sedex targets in the North Devon area (as shown in Figure 10). 